\title{
Trade policy shocks in the UK textile and apparel value chain: Firm perceptions of Brexit uncertainty
}

\author{
Patrizia Casadei ${ }^{1,2}$ and \\ Simona lammarino ${ }^{1}$
}

\footnotetext{
${ }^{1}$ Department of Geography \& Environment, London School of Economics and Political Science, Houghton Street, London WC2A $2 A E, U K{ }^{2}{ }^{\text {Science }}$ Policy Research Unit (SPRU), University of Sussex, Jubilee Building, Falmer, Brighton BN1 9RH, UK

Correspondence:

P Casadei, Department of Geography \& Environment, London School of Economics and Political Science, Houghton Street, London WC2A 2AE, UK

e-mail: p.casadei@lse.ac.uk
}

\begin{abstract}
Since the 2008 economic and financial crisis, the rise of populism and nationalism has been associated with increased protectionism and policy uncertainty in the world trade system, with profound side effects for international business (IB) activities and global value chains (GVCs). The aim of this paper is to investigate the way trade policy uncertainty linked to Brexit has affected firms' behaviors along the GVC of the UK textile and apparel (T\&A) industry. We draw upon data from an original survey carried out between June 2019 and January 2020 with 688 firms amongst UK T\&A manufacturers, designers, and retailers to grasp their perception of Brexit uncertainty. We show that the uncertainty over trade policy between the UK and the EU - started in the wake of the 2016 referendum - has affected a significant number of firms operating upstream and downstream of the UK T\&A value chain, which shows clear signs of ongoing restructuring. Our findings also provide some preliminary evidence of the way the (perceived) effects of trade policy uncertainty may vary depending on firms' position, production phase, and degree of integration in the GVC. Policy directions for supporting the UK T\&A value chain post-Brexit and implications for future IB research are discussed.
\end{abstract}

Journal of International Business Policy (2021) 4, 262-285.

https://doi.org/ | 0.1057/s422 | 4-020-00097-z

Keywords: trade policy; global value chains; survey method; Brexit; uncertainty; textile and apparel industry

\section{INTRODUCTION}

In the aftermath of the 2008 global economic crisis, the strength of populist and nationalist political attitudes has given rise to a new wave of protectionism and the cross-country emergence of trade discriminatory measures harming foreign commercial interests (Evenett, 2019; Evenett \& Fritz, 2019). These trends have affected the global trade system, injecting new political and economic uncertainties and reshaping firms' international production networks (Davis, 2019; Van Tulder et al., 2020). In the field of international economics, there is now a sizable body of empirical research supporting the proposition that trade policy uncertainty (TPU) has a negative impact on international trade (e.g., Crowley et al., 2018; Handley \& Limão, 2015, 2017), which now mostly
Received: 10 December 2019

Revised: 21 November 2020

Accepted: 11 December 2020

Online publication date: 8 February 2021 
involves global value chains (GVCs) with stages of the same production process dispersed across multiple countries and firms (De Backer \& Flaig, 2017). TPU, which has profound side effects for international business activities and firms' operations along the GVC, has recently become one of the grand challenges of international business (IB) research. Thus, to identify novel strategies for firms to operate internationally in this highly turbulent world (Buckley et al., 2017), more research effort is needed in the IB field to explore the way trade policy shocks and uncertainty affect the structure and configuration of GVCs (Van Assche \& Gangnes, 2019).

Brexit $^{1}$ - which refers to the withdrawal of the United Kingdom (UK) from the European Union (EU) - offers an almost ideal setting to investigate this issue. It represents an unexpected, unique, and large trade shock capable of disrupting trade, GVCs, and their dense production links spanning within and beyond Europe (e.g., Cappariello et al., 2018; Fusacchia et al., 2019; Vandenbussche et al., 2017). The potential negative effects of Brexit on trade and GVCs clearly originate from economic predictive models, particularly as Brexit negotiations are underway and there is still no clarity on the final form it will take (i.e., deal or no-deal). However, the persistent uncertainty over future trade policy between the UK and EU, started with the Brexit referendum in June 2016, has already affected the UK economy and firms in terms of financial markets and exchange rates volatility, a slowdown in gross domestic product (GDP) growth and a decline in purchasing power, productivity, outward and inward investments and trade flows (e.g., Bank of England, 2019; Bloom et al., 2019a, b; Crowley et al., 2018; De Lyon \& Dhingra, 2019; Dhingra \& Sampson, 2019). While evidence of the impact of this uncertainty on firms' behaviors remains limited due to the lack of granular micro-level data, no studies have looked at the impact on businesses from a GVC perspective.

The aim of this paper is to investigate the way trade policy uncertainty linked to Brexit has so far affected firms' behaviors along the GVC of the UK textile and apparel industry (T\&A). To do this, we draw upon data from an original survey carried out with 688 firms operating both upstream and downstream in the T\&A value chain - i.e., manufacturers, designers, and retailers - to grasp their perception of Brexit uncertainty. The GVC analysis allows us to also explore whether Brexit uncertainty has diversely affected firms with different positions, production phases, and degree of integration in the GVC. As is well known, T\&A is one of the oldest, most globalized, and leading export industries in the world, characterized by a highly complex and fragmented GVC that has been over time profoundly affected by different trade regimes and restrictions (e.g., Gereffi \& Frederick, 2010). Scholarly work has shown that this industry has the largest projected percentage decrease in output and value added in exports under any Brexit scenario (Fusacchia et al., 2019; Gasiorek et al., 2018). Additionally, this mature and labor-intensive sector, usually dominated by micro and small firms and highly integrated in GVCs with a large share of imported intermediate goods, can be included amongst those industries most exposed to trade policy uncertainty (Douch et al., 2019; Osnago et al., 2018). Undoubtedly, both TPU and the final UK withdrawal from the EU, either in a deal or nodeal scenario, have the potential to bring several challenges to the UK T\&A industry and its value chain.

The paper is organized as follows. Section two discusses the recent rise in trade policy uncertainty and its implications for international business activities, GVCs, and IB research. Moreover, on the basis of the existing literature, it discusses the implications of Brexit for trade and GVCs as well as the first observed consequences of Brexit uncertainty. The third section focuses first on the general role played by trade agreements in the T\&A value chain and then, more specifically, on the UK industry and the possible consequences of Brexit. The fourth section describes the methodology and data employed for the analysis, while the findings are discussed in the fifth section. The last section discusses the implications of trade policy uncertainty for firms' behaviors and the structure of GVC, indicates some necessary actions to support the UK T\&A value chain in the post-Brexit world, and provides recommendations for future IB research.

\section{TRADE POLICY UNCERTAINITY, GVCS, AND BREXIT}

\section{The Rise in Trade Policy Uncertainty: A New Challenge for IB Research}

Since the end of the 1970s, trade liberalization has played a key role in favoring trade integration and the rise of GVCs (Gereffi, 2019) ${ }^{2}$ by creating environments that encourage firms to slice up their 
value chains through foreign direct investments, offshoring and outsourcing, connect cheaply and effectively with foreign partners, and disperse production activities across the globe. The reduction or elimination of tariffs, non-tariff ${ }^{3}$, and other barriers to trade have been essential to the smooth functioning of global value chains. The participation in regional trade agreements is amongst those trade policies most favoring backward and forward GVC integration (De Backer \& Flaig, 2017; McKinsey Global Institute, 2019; Mulabdic et al., 2017). Nowadays, along with the North American Free Trade Agreement (NAFTA) ${ }^{4}$ and the ASEAN Free Trade Area (AFTA) ${ }^{5}$, the European Union hosts the main regionally embedded value chain in the world and the largest due to its economic size and degree of integration (Comotti et al., 2020; Escaith, 2018; Miroudot et al., 2013). In short, the production of goods and services has become increasingly fragmented across national boundaries and international trade is now characterized by final products that incorporate intermediate inputs from multiple origins (e.g., Gereffi \& Sturgeon, 2013; Van Assche \& Gangnes, 2019).

However, the prevailing trend of promoting international trade and investment was disrupted by the 2008 economic and financial crisis: since then, nationalist and populist political attitudes have led to an increasing number of discriminatory and contractionary trade measures introduced to strengthen domestic industries and protect them from foreign competitors (De Backer \& Flaig, 2017). During the "Populist era" in 2018 and 2019, governments worldwide introduced more than 2000 policy interventions with trade restrictions for foreign firms, a sharp rise compared to the rate documented at the beginning of the global financial crisis (Evenett, 2019; Evenett \& Frits, 2019). Such increased protectionism has created a serious challenge to globalization and international trade, which have experienced a slowdown in the aftermath of the crisis. In particular, it has injected new economic and political uncertainties into the global economy, with profound side effects for international business activities, trade flows, and the configuration of GVCs (Baker et al., 2019; Baldwin, 2016; Constantinescu et al., 2019; Davis, 2019).

One of the emerging challenges of IB research is to understand the way this new wave of protectionism, and more specifically trade shocks and policy uncertainty, affect international business activities to identify possible strategies for firms to operate globally in this highly turbulent world (Buckley et al., 2017). In the IB context, the acronym VUCA (Volatility, Uncertainty, Complexity, and Ambiguity) ${ }^{6}$ has been growingly adopted to summarize in one word the high levels of instability that the business world is experiencing (Van Tulder et al., 2020). Although uncertainty has been included in the development of international business theory and empirical research since the 1990s, most uncertainty-related studies in IB have focused on environmental, technological, and home/host market uncertainty (Celly et al., 1999; Matanda \& Freeman, 2009; Song, 2013); little research has so far addressed the policy uncertainty dimension, and specifically that of trade policy uncertainty (Delios \& Henisz, 2003; Nguyen et al., 2018).

In the field of international economics, there is now an extensive body of theoretical and empirical work that studies the effects of policy uncertainty on macroeconomic outcomes and firms' behaviors. A variety of studies find evidence that high (policy) uncertainty increases financial market volatility (Pastor \& Veronesi, 2013), delays costly and irreversible firm investments (Bernanke, 1983; Bloom et al., 2007; Dixit, 1989), reduces employment and productivity (Baker et al. 2016; Bloom, 2009; Pierce \& Schott, 2016), and depresses consumption expenditures (Gilchrist et al., 2014). Additionally, it lowers trade participation by affecting firms' decisions to source inputs internationally or serve foreign markets (Constantinescu et al., 2019; Taglioni \& Zavacka, 2012). For example, in response to an uncertainty shock, firms may take precautionary steps to source domestically or adjust their inventory policy by cutting foreign orders (Novy \& Taylor, 2014).

A number of recent studies point to the negative effects of trade policy uncertainty on firms' investments and participation in international markets (Crowley et al., 2018; Handley, 2014; Handley \& Limão, 2015). The negative effects of TPU on trade are higher for labor-intensive industries characterized by the presence of micro and small exporters usually financially constrained and less capable of quickly adjusting their production in response to trade shocks - differentiated goods providers ${ }^{7}$ and a large share of imported intermediate goods (Douch et al., 2019; Handley \& Limão, 2017). Several authors have argued that trade policy uncertainty has a higher negative impact on trade when production takes place in global value chains (Osnago et al., 2018). Indeed, uncertainty becomes a source of agglomeration for securing timely 
delivery of components when production is fragmented across stages of the value chain that are physically separated and dispersed across countries (Harrigan \& Venables, 2006). GVCs also exacerbate trade decline in the transmission of shocks through the production linkages across countries, with imported intermediate inputs acting as conduits (Cappariello et al., 2020; Sun Tam, 2018). Therefore, more research efforts are needed to understand how trade policy shocks and uncertainty affect international business operations along GVCs as well as their structure and configuration (Van Assche \& Gangnes, 2019).

\section{Short- and Long-Term Consequences of the Brexit Trade Shock}

\section{The (predicted) impact of Brexit on trade and GVCs}

One of the arguments for leaving the EU as explained by proponents of the "hard Brexit" line is to regain control over trade policies and draw more favorable deals with third countries ${ }^{8}$, particularly with the largest trading partners such as the United States, China, and India, a strategy called "Global Britain" (Brakman et al., 2017; Curran, 2018; UK Government, 2019). However, the implementation of Brexit, particularly constrained by the difficulties in defining a new trade agreement with Europe, points to the risk of bringing serious disruptions to trade and GVCs particularly in terms of tariffs, quotas, and other non-tariff barriers.

The EU - a single market and partial monetary union - is highly integrated in terms of GVCs so that the dense production networks involving its member states are often called "Factory Europe" (Baldwin \& Lopez-Gonzales, 2015; Cappariello et al., 2018; Comotti et al., 2020). The completion of the EU Customs Union (CU) in 1968 and of the Single Market by 1993 have hugely enabled withinarea cross-border integration of production chains, shortened delivery times, and lowered trade costs. As is known from the theory of economic integration (Balassa, 1961), CU is a type of free-trade area involving common external tariffs for imports from third countries and the abolition of customs checks amongst the partners, including those on the rules of origin". The single market is founded on the " 4 freedoms principle" - i.e., free movement of people, capital, goods, and services - within the European Economic Area $(E E A)^{10}$, the eradication of remaining tariffs and non-tariff barriers, and the adoption of a common EU regulatory framework (e.g., employment, consumer protection, environmental, social, and competition policies).

Several studies aimed at forecasting the consequences of "hard Brexit" have shown that it is unlikely that UK exports to non-European countries, particularly (but not exclusively) because of larger geographic distances, will increase sufficiently to compensate for the losses in trade with the EU (Ijtsma et al., 2018). Both in a no-deal scenario, where trade between EU and the UK would be regulated according to the WTO rules ${ }^{11}$, and with a free trade agreement (FTA) ${ }^{12}$ on the terms of access to specific markets, the cost of trade will increase in terms of market access measures, administrative burden, and behind-the-border rules that define the extent of non-tariff barriers (Gasiorek et al., 2018). Furthermore, leaving the EU CU will require the introduction of custom checks at the UK-EU borders. At the time of writing, goods are likely to have to satisfy rules of origin requirements, and trade will be exposed to the threat of anti-dumping duties and countervailing measures. Similarly, leaving the EU single market will lead to the introduction of checks to ensure the compliance of goods and services with the EU regulatory framework, where possible divergences could further increase trade costs $^{13}$. It will also mean restricted movement of people and labor force, with wide implications particularly for those sectors of the UK economy that are more reliant on EU migrant workers (Salh et al., 2017). As Bailey \& Budd (2017: 7) put it, "The free movement of labor is the most contentious and difficult issue as the Brexit negotiating strategy of the current UK government emerges".

UK industries are deeply interdependent with those in the rest of Europe through complex crossborder supply chains. The EU has been so far the UK's most important trading partner, which accounts for around half of its trade, representing a key driver of its position in the global economy (Dhingra, 2019). The EU membership has particularly contributed to the UK's - and all member states' - integration in GVCs. Trade policies implemented in one country of the continent, and associated with adverse shocks, are likely to have a "cascading" effect in the GVC context, affecting other firms, regions, and countries within the area and beyond. Therefore, a significant proportion of value chains within and outside the EU countries 
could be affected by Brexit in terms of direct and indirect trade relationships (Ijtsma et al., 2018; Mulabdic et al., 2017).

The majority of studies focusing on empirically exploring the implications of Brexit for the UK and its trading partners in Europe and internationally points to four main findings. First, Brexit has been predicted to negatively affect both the UK and, to a lesser extent, the EU whatever the deal scenario, in terms of value-added, employment, and trade costs (e.g., Cappariello et al., 2018; Vandenbussche et al., 2017). Second, unsurprisingly, the impact of Brexit on trade and foreign direct investment (FDI) will be strongly negative and more severe in the case of a no-deal Brexit and, more specifically, for denser GVCs (e.g., Cappariello et al., 2020; Dhingra et al., 2016; Mulabdic et al., 2017). Third, Brexit may also affect extra-EU countries engaged with FDI or sourcing relationships with the UK (e.g., Ijtsma et al., 2018). Fourth, there is a considerable heterogeneity in the way different sectors will be affected by Brexit. For example, while higher trade costs will harm the UK manufacturing industry under any Brexit scenario, textile, clothing, and footwear is one of the sectors with the largest projected percentage decrease in output and value added in exports in all settings (e.g., Fusacchia et al., 2019; Gasiorek et al., 2018).

\section{Brexit uncertainty}

The Brexit referendum in June 2016 initiated a "renegotiation regime" - a period of high uncertainty over future trade policy characterized by a change in the probabilities over possible future tariffs and non-tariff barriers. More than 4 years later, it is still uncertain how the economic relationship between the UK and the EU will evolve. Bloom et al. (2019a), drawing upon data from a large representative survey of the UK business population, find that since the referendum Brexit has been an important source of uncertainty for around $40 \%$ of UK-based firms. Uncertainty, which has been higher in industries more dependent on trade with the EU and on EU migrant labor, has mostly involved the impact of Brexit on market access, availability of skills and labor, and customs and product regulation.

Recent literature has begun analyzing the effect of Brexit uncertainty on the UK economy. The most immediate reaction after the referendum was an unprecedented depreciation of the pound sterling (Dhingra, 2019). The financial instability has been passed on to a higher consumer price index, with negative consequences for the purchasing power of households and their consumption and investment expenditure (Dhingra \& Sampson, 2019). The Bank of England (2019) highlights that uncertainty has made households and businesses more pessimistic about the economy, mostly affecting large purchases and discretionary spending. Moreover, costs of intermediate inputs have increased, the value of imports into the UK has been lower, export demand has decreased because of more cautious overseas customers, and both inward and outward FDI have dropped. Overall, there has been a slowdown in UK's GDP growth, and firms have experienced lower productivity (Bloom et al., 2019b; De Lyon \& Dhingra, 2019). Uncertainty has particularly affected the UK manufacturing sector, with job losses resulting from negative sales, decrease in output and orders because of customers postponing capital spending and firms stockpiling raw materials and struggling financially (The Guardian, 2019a).

Furthermore, on the impact of Brexit uncertainty on trade, Crowley et al. (2018) show that Brexit uncertainty has reduced exports to the EU across all industries, leading to a significant decline in the number of entrants into exporting to the EU, and an increase in the number of firms exiting from exporting to the EU. Graziano et al. (2018) find that Brexit uncertainty has already induced a reduction in UK-EU bilateral trade flows, with larger negative effects of Brexit uncertainty on EU exports relative to UK exports. Similarly, Douch et al. (2019) show that uncertainty over the future UK-EU trade regime has caused firms' exports/imports to be diverted away from the EU to extra-EU markets. They also find that smaller traders have been the most heavily influenced by uncertainty, due to their constrained resources and reliance on exports to closer EU markets of fewer products more exposed to future tariffs. Graziano et al. (2020) and Hassan et al. (2020) show that Brexit imposes policy uncertainty externalities to non-EU countries, which will be subject to a long renegotiating process for a new trade agreement with the UK.

In addition, under Brexit uncertainty, we can expect that firms' GVC position may be differently sensitive to price changes originating from sterling depreciation. For example, while a depreciation of the exchange rate raises the cost of imported inputs, affecting firms involved in backward linkages and the cost of domestic production, it also reduces the price of exports, making firms involved in forward linkages with foreign countries more 
competitive. Thus, it is likely that Brexit uncertainty has differently affected firms, depending on their position and degree of integration in the GVC.

\section{WHAT DOES BREXIT MEAN FOR THE TEXTILE AND APPAREL INDUSTRY VALUE CHAIN?}

\section{The Role of Trade Agreements in Reshaping the Global T\&A Value Chain Configuration}

T\&A is one of the oldest, most globalized and leading export industries in the world, as well as a significant engine for economic growth (Gereffi, 1999; Gereffi \& Frederick, 2010). In particular, due to its low fixed costs, low technology- and high labor-intensive manufacturing, it has been deeply involved in the global slicing up of production stages, witnessing a long-term steady increase in offshore production and a later consolidation at the retail end of the value chain (Macchion et al., 2015). The GVC of the textile and apparel industry is highly complex, geographically fragmented, and characterized by large power asymmetries. It is a classic example of a "buyer-driven" value chain, where lead firms, such as retailers, designers, and brand manufacturers, play a key role in the organization of global production, acting as strategic brokers in linking dispersed networks of overseas suppliers with final consumer markets. Lead firms, which are usually located in advanced countries, perform the most valuable activities in the value chain (e.g., research, design, branding, marketing) and control access to major resources generating the most profitable returns. Suppliers, which have been typically located in low-cost developing economies, carry out various phases of the production process in accordance to lead firms' specifications (Fernandez-Stark et al., 2011; Gereffi, 2019; Pickles et al., 2015).

Over time, different trade regimes, including restrictive and liberalization measures, have generated major shifts in global sourcing dynamics and governance of GVCs. Between 1974 and 2004, the ability of developing countries to enter the T\&A industry was limited by a complex system of constraints on the volume of exported items. These trade restrictions, part of the Multi-Fibre Arrangement (MFA), were aimed at protecting domestic industries in advanced economies from highly competitive low-cost suppliers such as China and India. Nevertheless, the MFA prompted the rise of value chain intermediaries, the establishment of factories in places with available quotas, and the entry of new players from developing locations in the export market sheltered from leading low-cost competitors, thus fueling the spread of GVCs (Gereffi, 1999). Later, the removal of quota-constrained trade under the WTO's Agreement on Textile and Clothing (over the period 1995-2005) led to a gradual rationalization and consolidation of the value chain (Fernandez-Stark et al., 2011).

On the one hand, lead firms, also spurred by the development of fast fashion systems and the growing specialization of T\&A products, have enacted a profound process of restructuring of their sourcing networks by developing longer-term relationships with a restricted number of more efficient and strategically located suppliers (Pickles et al., 2015). On the other hand, suppliers from developing countries have benefited from organizational learning processes arising from these longer and more stable relationships with lead firms by "upgrading" into higher-value activities and improving their position in the value chain. Industrial upgrading is usually associated with the shift from the mere assembly of products (CMT - Cut, Make, Trim) to full production models (OEM - Original Equipment Manufacturing), and more domestically integrated forms of manufacturing involving design (ODM - Original Design Manufacturing) and branding activities (OBM - Original Branding Manufacturing). This process can take many forms, ranging from the acquisition of new higher-value functions (i.e., functional upgrading), the production of more complex products (i.e., product upgrading), an increase in efficiency by reorganizing production systems or using more sophisticated technologies (i.e., process upgrading) and the entry into new industries (i.e., intersectoral upgrading) (Fernandez-Stark et al., 2011).

As a result of these changes, the T\&A value chain has gradually shifted from a "captive" model, characterized by a high degree of monitoring and control by lead firms on suppliers, to a "relational" model where the power balance between these types of firms is more symmetrical. Moreover, changing conditions in low-labor cost countries and evolving dynamics in industrialized countries, such as technological improvements or increasing emphasis on production control, shorter lead times and proximity to final markets, as well as concerns for environmental and ethical standards, have led to growing awareness of the importance of combining local and global sourcing and production to optimize the tradeoff between cost savings and 
flexibility along the value chain (Macchion et al., 2015). Over the last decade, the T\&A industry, which has seen a growing number of lead firms relocating parts of their production activities back to their home country, has attracted increasing attention from scholars exploring the reshoring phenomenon (Fratocchi \& Di Stefano, 2019; McKinsey \& Company, 2019a; Robinson \& Hsieh, 2016).

\section{The UK T\&A Industry and the European Integration}

The T\&A industry was at the heart of the industrial revolution that pushed the UK to the leadership of the global economy in the late 18th and 19th century, representing for many decades one of the largest sources of employment in the country. However, T\&A began to decline in the 1970s, with firms massively outsourcing and offshoring production to low-wage countries, and jobs almost disappearing from the UK regions that were once the core of the industry. Since then, the revitalization of this industry has been the object of specific public policies discourses, such as the London Industrial Strategy (GLC, 1985). In the late 1990s, the government established the Textiles and Clothing Strategy Group to improve the ability of the industry to compete internationally by restructuring the supply chain, supporting designers, improving education and training, as well as promoting innovation and investment (DTI, 2000). While the strategy made a positive contribution in re-orienting London into a global fashion center, it failed to stop manufacturing decline. Later, in the 2008 revision of the UK industrial strategy, the industry was not on the agenda anymore. Yet, the UK has retained world-leading capabilities in both fashion design and retailing, dominating the top ten of clothing retailers by turnover in 2018 and being the home of some of the world's most creative and innovative design fashion labels.

Although the UK industry still produces a relatively small proportion of T\&A products sold domestically and globally (Froud et al., 2017), it has experienced for the first time a considerable renewed growth following the economic recession. A variety of scholars, industry organizations, and institutional bodies have discussed a potential resurgence of the industry (BFC, 2015; Hammer \& Plugor, 2016; Robinson \& Hsieh, 2016; The Alliance Project, 2017; UKFT, 2018b; Worrell \& Miller, 2018). Between 2013 and 2017, manufacturing employment in the industry increased by $28 \%$ accounting for approximately 109,000 people (excluding self-employed) in 2017. ${ }^{14}$ Between 2009 and 2015, productivity increased from $£ 7.6$ to $£ 9.1$ billion, and GVA from $£ 2.5$ billion to $£ 3.3$ billion. In 2017, UK fashion and textile exports accounted for $£ 9.7$ billion, recording a $66 \%$ increase since 2008. Over the last decade, there has been increasing evidence of a growing demand amongst designers, brand owners, and retailers (e.g., Mulberry, Burberry, John Lewis, Marks \& Spencer) for increasing the proportion of products manufactured in the UK, particularly because of shorter lead times and increased flexibility (Financial Times, 2014; Robinson \& Hsieh, 2016); a trend seemingly enhanced by uncertainties brought by both Brexit and, more recently, the COVID-19 pandemic (Financial Times, 2014). Likewise, there has been growing interest in the "Made in Britain" brand, with several domestic retailers capitalizing on this label by launching their British-made ranges and more overseas customers interested in buying UK-made garments (Froud et al., 2017).

The industry has particularly benefitted from being part of the EU single market and customs union. First, the T\&A industries of the UK, EU27, and other European neighboring countries are closely interlinked in terms of supply chains, FDI, and exchange of workers. The EU-UK textile trade was worth $£ 14$ billion in the period 2014-2016: on average the UK imported $£ 8.7$ billion worth products from the EU27, while its exports amounted to $£ 5.3$ billion. The EU has played a key role in the UK supply chain and is by far the largest destination for UK fashion and textile exports, accounting for 74\% of its exports in 2016. In the same year, imports from the EU accounted for $32 \%$ of total UK imports. In 2015, the UK was the EU's secondlargest clothing import market in volume terms, with a $22 \%$ share of EU clothing imports (Euratex, 2017; UKFT, 2018b). Thanks to the Generalised System of Preferences (GSP), an import regime favoring access to developing economies, UK retailers and brands have been able to access duty-free T\&A goods from countries such as Bangladesh and Pakistan, which represent key import markets. Likewise, Turkey, which is covered by the EU CU with duty-free market access, has become the UK's third-biggest apparel market (behind China and Bangladesh) and the eighth-biggest market for textiles (UKFT, 2018b). Second, the access to skilled talent from the EU has been vital to the sector. Many leading European designers have established their businesses in the UK, after attending world- 
leading fashion design schools. Also, the manufacturing sector, because of the shortage of skilled national employees, has often been forced to recruit workers from other European countries (BFC, 2015; BOP Consulting, 2017). For example, it was recently estimated that around $70 \%$ of the London clothing manufacturing firms' workforce comes from the EU (UKFT, 2018a). Third, EU intellectual property rights (IPRs) regulations have provided the industry with a framework to effectively protect its innovation and creativity. Fourth, EU research programs have been a significant source of funding for R\&D in the industry: over 10,000 UK businesses received support under the EU's Seventh Framework Programme for Research (2007-2013), accounting for some $£ 1.2$ billion of investment, and over 1000 firms have received total funds amounting to $£ 411$ million under Horizon 2020. Based on patent generation between 2000 and 2015 , the UK textile industry is ranked number 3 in the world and number 1 in Europe for textile innovation (The Alliance Project, 2017; UKFT, 2018a).

\section{Brexit and the UK T\&A Industry}

As an industry that strongly relies on export revenues, raw materials from abroad, a highly complex supply chain, and an international talent pool, the new post-Brexit trade regime is deemed to bring several challenges to the T\&A sector and to the configuration and dynamics of its value chain (e.g., BFC, 2019; Gasiorek et al., 2018; McKinsey \& Company, 2019b; UKFT, 2018a).

While the form of a future trade deal is still unknown, there is enough clarity on what a no-deal scenario would imply for the UK T\&A industry. Failure to reach a deal could undermine growth prospects significantly, particularly in the short term (BFC, 2019; Euratex, 2017). According to recent research from the UK Fashion and Textile Association (UKFT, 2019), a no-deal is expected to create significant disruption to the supply chain. In this scenario, UK exports to the EU would attract average tariffs of $4 \%$ for yarn, $8 \%$ for fabric, and $12 \%$ for clothing. The UK's new MFN tariff regime, UK Global Tariff, will replace the EU's Common External Tariff on January 1, 2021. In case of a nodeal Brexit, this tariff designed for imports from countries where the UK does not have a trade deal, would also apply to UK firms importing from the EU. Imports from vulnerable developing countries (e.g., Pakistan, Bangladesh, Cambodia, Sri Lanka, Vietnam, Myanmar) would still have reduced tariffs or duty-free access to the UK, because the government (for now) has committed to replicate the EU's GSP scheme. However, imports from Turkey would become $12 \%$ more expensive (UKFT, 2019). The restriction of free movement is another issue that is likely to affect the industry, which often relies on Eastern European workers (BFC, 2015; BOP Consulting, 2017; Froud et al., 2017; UKFT, 2018a). Indeed, many EU workers in the sector such as sewing machinists would be denied a UK visa under the proposed migration scheme, which is aimed at retaining only "high-skilled" jobs.

We can expect that this scenario will affect firms with both forward and backward linkages with European countries, and less firms with relational rather than captive linkages. An increase in the cost of UK textile and apparel could encourage European firms to quickly rethink their sourcing strategies, switching to suppliers from other countries. Additionally, UK firms sourcing textile and apparel from European firms could also choose to reconfigure parts of their linkages along the value chain, potentially favoring domestic manufacturing (Financial Times, 2016; Worrell \& Miller, 2018). Thus, an opportunity may arise for UK firms operating upstream of the value chain for undertaking a process of functional, product, and process upgrading. However, the tightening of immigration control could force start-up firms to relocate elsewhere and discourage the establishment of new firms.

Even in the event of a free trade agreement, nontariff barriers including customs checks and documentation requirements would result in delays, higher prices, and decrease in final output and exports (Fusacchia et al., 2019; UKFT, 2019). Indeed, leaving the $\mathrm{CU}$ means exporters would have to fill out declaration forms, which come with administrative costs. Also, additional documentation would be required to take samples to international exhibitions and tradeshows, which represent a first step into the world of exports. Unless some alternative agreement is reached, the cost for IPR protection would increase, and firms wishing to obtain registered protection for their brands and designs in Europe would need to apply for both UK and EU designs. The UK will also need to meet the EU regulatory framework associated with issues like consumer protection, environmental and social sustainability, and competition policy.

As the government is still negotiating trade agreements with the EU and other key markets for the industry such as the USA and China, it is not yet possible to envisage the actual impact of Brexit 
on the UK T\&A value chain. However, there is some first evidence that the industry has been hit by Brexit uncertainty and that some firms have also begun to rethink their sourcing strategies (Financial Times, 2020; The Guardian, 2019b). In particular, the existing literature on trade policy uncertainty emphasizes that the negative effects of TPU on trade are higher for mature and labor-intensive sectors that are highly integrated in GVCs, with high shares of imported intermediate goods and the presence of differentiated goods providers as well as of micro and small exporters. Therefore, there are additional grounds for believing that Brexit uncertainty, combined with "tariff scares" and high exchange rate volatility, may have already affected trading relationships in the T\&A industry.

\section{DATA AND METHODOLOGY}

The empirical investigation here presented draws upon an original survey designed by the authors to investigate: 1) the configuration of the UK T\&A industry in terms of supply networks, products, production systems, and actors involved (see Casadei \& Iammarino, 2020, for a detailed analysis of the survey); 2) the perceptions of Brexit uncertainty amongst firms operating upstream and downstream in the value chain. Using and crossreferencing different sources of data from the Orbis database published by Bureau van Dijk and online databases from industry associations (i.e., British Fashion Council, UK Fashion \& Textile AssociationUKFT and Make It British), a target population of UK manufacturing firms, retailers, and fashion designers was identified. When retrieving data from the Orbis database, the target group ${ }^{15}$ consisted of the Standard Industrial Classification (SIC) 2007 categories associated with T\&A manufacturing and fashion retailing ${ }^{16}$, including foreign subsidiary firms. We included both retailers owning their own brand and retailers selling other designers' brands. The definition of the final target population - 13,505 firms (3941 manufacturers and 9564 retailers) ${ }^{17}$ - was partially constrained by the difficulties in retrieving firms' missing e-mail addresses from the Orbis databases.

The survey ${ }^{18}$ was designed in strict accordance with the methodological guidelines of survey research (Forza, 2002). It was tailored ${ }^{19}$ to target both retailers/designers - namely those firms which perform the most valuable activities at the retail end of the value chain - and manufacturing firms, which operate upstream in the value chain and carry out production phases to meet the needs of retailers and designers. We relied upon the existing literature on the topic to identify and ensure a high level of validity of the 62 survey questions, which contained branching-namely conditional paths for respondents based on their answers to specific questions. The survey included a large range of questions about firms' main characteristics, supply chain relationships, sourcing and internationalization strategies, amongst the main issues investigated. Respondents were asked whether they had been affected by Brexit uncertainty, the main consequences and the type of changes undergone, as well as their overall perception of the UK's withdrawal from the EU.

The survey was pre-tested with several industry experts and a sample of ten target respondents amongst manufacturing firms, retailers, and designers to ensure the validity, quality, and accuracy of the questions. The test panel, which was conducted through face-to-face or telephone interviews, suggested only a few minor corrections. The survey distribution was supported and sponsored by the UK Fashion \& Textile Association (UKFT). Additional offline data collection was executed on May 29th and 30th, 2019, during the Make It British event, a trade show that hosted many UK manufacturing firms from our population. The survey was distributed online between June 2019 and January 2020. In order to accurately monitor the response rate, the survey was distributed electronically to randomized samples from the population of interest in different periods of time, and nonrespondents were solicited with four reminders.

We collected 1006 responses (299 were partially completed), achieving a response rate of $7.5 \%$, which is a fairly satisfying response rate for an indepth large-scale survey in this type of industry, also given that the topic is a quite sensitive issue, and no incentives were offered (Baruch \& Holtom, 2008; Cook et al., 2000; Harzing et al., 2012). The sample was then cleaned to remove partially completed and duplicated responses. The final sample included 688 completed responses, 199 from manufacturing firms and 489 from retailers/designers and was tested for: (1) non-response bias by comparing early and late responses using a $t$ test comparison of mean, which proved insignificant; (2) comparison with known values of the population (Armstrong \& Overton, 1977), showing that our sample has characteristics similar to the population. Moreover, the final sample was qualitatively checked and validated by the UKFT. 
Survey data were examined both through descriptive statistics and text-mining techniques, which we adopted to analyze the content of the large amount of text originating from open-ended questions. Whereas general descriptive statistics and the analysis of open-ended comments focus on the entire sample of 688 completed responses, the more in-depth investigation on Brexit is based on the entire sample of 199 manufacturing firms and on a random sub-sample of retailers and designers including 143 responses ${ }^{20}$.

\section{FINDINGS}

\section{Descriptive Statistics: GVC Structure, Organization, and the Brexit Shock}

We present here a descriptive analysis of the information collected from the sample to explore and discuss the configuration of the UK T\&A value chain, as well as compare the main characteristics of manufacturing firms and retailers/designers with different perceptions of Brexit uncertainty.

Tables 1 and 2 summarize the main characteristics of manufacturing firms. Most of these companies are ODM and CMT micro-sized firms ${ }^{21}$ with less than ten employees, established before the 1990s, and specialized in the phases ranging from product design and development to the delivery of finished products, predominantly high-end womenswear and menswear T\&A. The majority of manufacturers supply both domestic and international independent fashion designers, small retailers, and brand manufacturers. A large share of their skilled workforce is originally from the UK, where it was also trained to develop manufacturing skills and competences. However, $35 \%$ of the skilled workforce comes from outside the UK (25\% from other European countries). A minority of firms (24\%) offshored production, mainly to extra-European countries and China, due to the access to skills and knowledge offshore as well as labor cost savings. A few firms $(23 \%$ amongst those that offshored) planned or implemented a reshoring strategy $^{22}$, mainly bringing garment making back using owned domestic facilities.

Turning to the Brexit shock, the majority of manufacturing firms in the overall sample (61\%) stated to have already been affected by Brexit uncertainty over the previous three and half years. The distribution of these firms is slightly skewed towards larger firms with more than ten employees, if compared to those firms that declared not to have been affected so far (51 vs 38\%). With respect to the group of non-affected, firms that already experienced some consequence of Brexit show a higher percentage of European skilled workers (30 vs 15\%) and a lower percentage of skilled workforce that was entirely trained in the UK (62 vs $78 \%$ ). The same affected firms have a higher share of retail companies as main customers (48 vs $35 \%$ ), which are also more international (63 vs $40 \%$ ); in terms of sourcing relationships, they have a higher portion of production phases related to raw materials and textiles offshored (40 vs 13\%) and a lower share associated with garment making (17 vs 31\%). Moreover, they offshored production more to extra-EU countries (74 vs $50 \%$ ).

Thus, manufacturing firms more integrated in the GVC, more involved in backward linkages with extra-EU suppliers, and supplying more international customers seem to perceive more the impact of Brexit uncertainty. Conversely, $64 \%$ of manufacturing firms that moved towards a more domestic supply chain through reshoring and therefore less involved in GVC stated not to have faced any consequence yet. Moreover, the type of production phases offshored seems to affect the perceived consequences of Brexit, with firms offshoring production phases that involve inputs and components more sensitive to uncertainty. This can be explained by the higher reliance of these firms on external foreign suppliers for manufacturing stages at the very upstream of the value chain, and the resulting higher concerns for potential disruptions of their entire production process.

Tables 3 and 4 show that the majority of retail and fashion design firms in the Brexit-related sample have less than ten employees, were established over the last decade, and operate both in the domestic and online market. Alongside finishing processes and product delivery, most of these firms, which are represented by independent fashion designers, fashion retailers, and brand manufacturers, have their own brand and focus on product design and development of both "accessible" and "premium" womenswear and menswear apparel and accessories. As far as global sourcing strategies are concerned, $43 \%$ of these firms implemented an offshoring strategy. Their host locations are primarily in extra-European countries and China, which together account for $65 \%$ of total offshore production; similarly to manufacturers, the main reasons for offshoring were access to skills and knowledge in addition to labor cost savings overseas. Amongst those retailers and designers that 
Table 1 Sample's characteristics of manufacturing firms-1.

\begin{tabular}{|c|c|c|c|c|}
\hline \multicolumn{5}{|c|}{ Manufacturing firms (percent frequency) } \\
\hline Variable & Category & $\begin{array}{c}\text { Total } \\
(N=199)\end{array}$ & $\begin{array}{l}\text { Affected by Brexit } \\
\qquad(N=122)\end{array}$ & $\begin{array}{l}\text { Not affected by } \\
\text { Brexit }(N=77)\end{array}$ \\
\hline \multirow[t]{4}{*}{ Year of establishment } & 1990s and earlier & 57.79 & 60.66 & 53.25 \\
\hline & 2000-2009 & 17.09 & 16.39 & 18.18 \\
\hline & 2010-2014 & 14.57 & 13.93 & 15.58 \\
\hline & 2015-2018 & 10.55 & 9.02 & 12.99 \\
\hline \multirow{4}{*}{ Number of employees } & 0-9 (micro) & 54.27 & 49.18 & 62.34 \\
\hline & 10-49 (small) & 30.15 & 31.97 & 27.27 \\
\hline & 50-249 (medium) & 13.07 & 16.39 & 7.79 \\
\hline & $250+($ large $)$ & 2.52 & 2.46 & 2.60 \\
\hline \multirow[t]{16}{*}{ Type of products* } & Raw materials & 2.22 & 1.94 & 2.64 \\
\hline & Semi-finished products & 5.80 & 7.61 & 3.12 \\
\hline & Finished products & 13.43 & 13.43 & 13.43 \\
\hline & Womenswear & 13.24 & 13.11 & 13.43 \\
\hline & Menswear & 11.98 & 12.30 & 11.51 \\
\hline & Childrenswear & 7.15 & 6.47 & 8.15 \\
\hline & Textiles & 8.21 & 9.55 & 6.24 \\
\hline & Apparel & 9.86 & 9.71 & 10.07 \\
\hline & Underwear & 1.16 & 1.29 & 0.96 \\
\hline & Outwear & 6.18 & 5.83 & 6.71 \\
\hline & Bridalwear & 1.74 & 1.62 & 1.92 \\
\hline & Footwear & 1.16 & 1.62 & 0.48 \\
\hline & Leather goods & 2.71 & 2.75 & 2.64 \\
\hline & Accessories & 5.31 & 3.88 & 7.43 \\
\hline & Sportswear & 3.48 & 2.43 & 5.04 \\
\hline & Swimwear & 1.45 & 1.29 & 1.68 \\
\hline \multirow[t]{10}{*}{ In-house functions/processes* } & Fibers to yarns & 2.08 & 2.53 & 1.25 \\
\hline & Yarns to fabrics & 6.13 & 6.91 & 4.67 \\
\hline & Coloring and finishing & 4.81 & 4.89 & 4.67 \\
\hline & Textile inspection and evaluation & 7.99 & 8.77 & 6.54 \\
\hline & Product design and development & 15.86 & 15.51 & 16.51 \\
\hline & Prototype preparation & 11.38 & 12.14 & 9.97 \\
\hline & Sample development & 15.21 & 15.51 & 14.64 \\
\hline & Garment making & 12.04 & 10.46 & 14.95 \\
\hline & Pressing/finishing/packaging & 11.27 & 10.62 & 12.46 \\
\hline & Product delivery & 11.49 & 11.13 & 12.15 \\
\hline \multirow[t]{4}{*}{ Main production model ${ }^{*}$} & Cut, Make and Trim & 20.60 & 18.85 & 23.38 \\
\hline & Original Equipment Manufacturing & 12.56 & 14.75 & 9.09 \\
\hline & Original Design Manufacturing & 36.68 & 36.89 & 36.36 \\
\hline & Original Brand Manufacturing & 15.08 & 16.39 & 12.99 \\
\hline \multirow[t]{3}{*}{ Market position } & Mass-market & 11.56 & 10.66 & 12.99 \\
\hline & Accessible/Middle-market & 37.19 & 37.70 & 36.36 \\
\hline & High-end & 51.26 & 51.64 & 50.65 \\
\hline \multirow[t]{7}{*}{ Type of customers* } & Independent designers & 19.15 & 17.57 & 22.16 \\
\hline & Large fashion retailers & 9.04 & 10.00 & 7.22 \\
\hline & Small fashion retailers & 15.43 & 16.76 & 12.89 \\
\hline & High street retailers & 9.57 & 10.54 & 7.73 \\
\hline & Boutiques & 9.75 & 11.08 & 7.22 \\
\hline & Fashion houses & 10.11 & 10.00 & 10.31 \\
\hline & Brand manufacturers & 13.65 & 12.43 & 15.98 \\
\hline \multirow[t]{3}{*}{ UK-based customers } & Yes & 46.23 & 36.89 & 61.04 \\
\hline & No & 1.01 & 1.64 & - \\
\hline & Both UK and internationally & 52.76 & 61.48 & 38.96 \\
\hline
\end{tabular}


Table 1 (Continued)

\begin{tabular}{|c|c|c|c|c|}
\hline \multicolumn{5}{|c|}{ Manufacturing firms (percent frequency) } \\
\hline Variable & Category & $\begin{array}{c}\text { Total } \\
(N=199)\end{array}$ & $\begin{array}{l}\text { Affected by Brexit } \\
\qquad(N=122)\end{array}$ & $\begin{array}{l}\text { Not affected by } \\
\text { Brexit }(N=77)\end{array}$ \\
\hline \multirow[t]{4}{*}{ UK-trained skilled workforce } & Yes & 68.34 & 62.30 & 77.92 \\
\hline & No & 12.56 & 13.11 & 11.69 \\
\hline & Only a few workers & 10.05 & 13.93 & 3.90 \\
\hline & The majority of workers & 9.05 & 10.66 & 6.49 \\
\hline \multirow[t]{4}{*}{ Skilled workforce's region } & United Kingdom & 65.06 & 58.29 & 77.66 \\
\hline & Eastern Europe & 17.10 & 18.86 & 5.32 \\
\hline & Western Europe & 7.81 & 11.40 & 9.57 \\
\hline & Extra-Europe & 10.03 & 11.40 & 7.44 \\
\hline
\end{tabular}

Table 2 Sample's characteristics of manufacturing firms-2.

\begin{tabular}{|c|c|c|c|c|}
\hline \multicolumn{5}{|c|}{ Manufacturing firms (percent frequency) } \\
\hline Variable & Category & $\begin{array}{c}\text { Total } \\
(N=199)\end{array}$ & $\begin{array}{l}\text { Affected by Brexit } \\
\qquad(N=122)\end{array}$ & $\begin{array}{l}\text { Not affected by } \\
\text { Brexit }(N=77)\end{array}$ \\
\hline \multirow[t]{2}{*}{ Offshored production } & Yes & 24.12 & 26.23 & 20.78 \\
\hline & No & 75.88 & 73.77 & 79.22 \\
\hline \multirow[t]{10}{*}{ Type of activity offshored* } & Fibers to yarns & 5.00 & 5.47 & 3.13 \\
\hline & Yarns to fabrics & 11.25 & 12.50 & 6.25 \\
\hline & Coloring and finishing & 10.00 & 11.72 & 3.13 \\
\hline & Textile inspection and evaluation & 8.13 & 10.16 & - \\
\hline & Product design and development & 3.75 & 3.91 & 3.13 \\
\hline & Prototype preparation & 7.50 & 8.59 & 3.13 \\
\hline & Sample development & 12.50 & 11.72 & 15.63 \\
\hline & Garment making & 20.00 & 17.19 & 31.25 \\
\hline & Pressing/finishing/packaging & 13.13 & 12.50 & 15.63 \\
\hline & Product delivery & 6.88 & 6.25 & 9.38 \\
\hline \multirow[t]{4}{*}{ Host geographical region } & Eastern Europe & 18.57 & 14.00 & 30.00 \\
\hline & Western Europe & 14.29 & 12.00 & 20.00 \\
\hline & China & 31.43 & 34.00 & 25.00 \\
\hline & Other extra-EU countries & 35.72 & 40.00 & 25.00 \\
\hline \multirow[t]{8}{*}{ Offshoring motivations* } & Access to skills and knowledge offshore & 27.27 & 27.71 & 25.93 \\
\hline & Labor cost savings & 33.64 & 31.33 & 40.74 \\
\hline & Trade facilitations & 4.55 & 4.82 & 3.70 \\
\hline & Country-specific conditions & 7.27 & 6.02 & 11.11 \\
\hline & Access to new markets & 1.82 & 2.41 & - \\
\hline & Access to raw materials & 9.09 & 9.64 & 7.41 \\
\hline & Access to advanced machinery & 9.09 & 10.84 & 3.70 \\
\hline & Risk diversification & 2.73 & 3.61 & - \\
\hline \multirow[t]{3}{*}{ Reshoring } & Implemented & 20.83 & 12.50 & 37.50 \\
\hline & Planned & 2.08 & - & 6.25 \\
\hline & Not planned & 77.08 & 87.50 & 56.25 \\
\hline
\end{tabular}

Source: Authors' own elaboration.

*The variable included the option "other". 
Table 3 Sample's characteristics of retailers/designers-1

\begin{tabular}{|c|c|c|c|c|}
\hline \multirow[t]{3}{*}{ Variable } & \multirow[t]{3}{*}{ Category } & \multicolumn{3}{|c|}{ Retailers/Designers (percent frequency) } \\
\hline & & \multirow{2}{*}{$\begin{array}{l}\text { Full sample } \\
(N=489)\end{array}$} & \multicolumn{2}{|c|}{ Brexit sample $(N=143)$} \\
\hline & & & $\begin{array}{l}\text { Affected by Brexit } \\
\qquad(N=88)\end{array}$ & $\begin{array}{l}\text { Not affected by Brexit } \\
\qquad(N=55)\end{array}$ \\
\hline \multirow[t]{4}{*}{ Year of establishment } & 1990s and earlier & 24.54 & 28.41 & 27.27 \\
\hline & $2000-2009$ & 19.43 & 29.55 & 12.73 \\
\hline & 2010-2014 & 19.84 & 19.32 & 12.73 \\
\hline & 2015-2018 & 36.20 & 22.73 & 47.27 \\
\hline \multirow[t]{4}{*}{ Number of employees } & 0-9 (micro) & 87.32 & 85.23 & 92.73 \\
\hline & 10-49 (small) & 11.25 & 14.77 & 3.64 \\
\hline & 50-249 (medium) & 0.41 & - & 3.64 \\
\hline & $250+($ large $)$ & 1.02 & - & - \\
\hline \multirow[t]{13}{*}{ Type of products } & Womenswear & 18.23 & 17.06 & 17.24 \\
\hline & Menswear & 10.95 & 9.45 & 11.33 \\
\hline & Childrenswear & 6.46 & 5.77 & 4.93 \\
\hline & Textiles & 5.17 & 4.72 & 5.91 \\
\hline & Apparel & 14.67 & 16.01 & 16.26 \\
\hline & Underwear & 3.41 & 3.15 & 3.45 \\
\hline & Outwear & 7.39 & 9.45 & 7.39 \\
\hline & Bridalwear & 3.36 & 3.15 & 2.96 \\
\hline & Footwear & 6.46 & 7.09 & 8.87 \\
\hline & Leather goods & 4.91 & 5.51 & 4.93 \\
\hline & Accessories & 12.09 & 12.60 & 10.34 \\
\hline & Sportswear & 4.18 & 3.94 & 3.94 \\
\hline & Swimwear & 2.74 & 2.10 & 2.46 \\
\hline \multirow[t]{6}{*}{$\begin{array}{l}\text { In-house functions/ } \\
\text { processes* }\end{array}$} & $\begin{array}{l}\text { Product design and } \\
\text { development }\end{array}$ & 23.87 & 29.80 & 30.40 \\
\hline & Prototype preparation & 11.69 & 13.64 & 13.60 \\
\hline & Sample development & 12.96 & 16.67 & 16.00 \\
\hline & Garment making & 9.77 & - & - \\
\hline & Pressing/finishing/packaging & 13.39 & 14.65 & 14.40 \\
\hline & Product delivery & 20.54 & 25.25 & 25.60 \\
\hline \multirow[t]{7}{*}{ Type of company* } & Independent designer & 22.70 & 11.36 & 27.27 \\
\hline & Large fashion retailer & 0.61 & - & - \\
\hline & Small fashion retailer & 16.77 & 17.05 & 14.55 \\
\hline & High street retailer & 4.09 & 6.82 & 1.82 \\
\hline & Boutique & 15.95 & 13.64 & 10.91 \\
\hline & Fashion house & 2.25 & 2.27 & 1.82 \\
\hline & Brand manufacturer & 11.04 & 10.23 & 14.55 \\
\hline \multirow[t]{3}{*}{ Own brand } & Yes & 66.46 & 63.64 & 67.27 \\
\hline & No & 27.81 & 28.41 & 25.45 \\
\hline & Both own and others & 5.73 & 7.95 & 7.27 \\
\hline \multirow[t]{4}{*}{ Market position } & Mass-market & 6.13 & 6.82 & - \\
\hline & Accessible/Middle-market & 38.85 & 42.05 & 38.18 \\
\hline & Premium & 33.95 & 31.82 & 38.18 \\
\hline & High-end & 21.06 & 19.32 & 23.64 \\
\hline \multirow[t]{3}{*}{ Type of market } & Domestic & 42.18 & 46.06 & 38.66 \\
\hline & International & 25.39 & 20.61 & 28.57 \\
\hline & Online & 32.44 & 33.33 & 32.77 \\
\hline
\end{tabular}


Table 4 Sample's characteristics of retailers/designers-2.

\begin{tabular}{|c|c|c|c|c|}
\hline \multirow[t]{3}{*}{ Variable } & \multirow[t]{3}{*}{ Category } & \multicolumn{3}{|c|}{ Retailers/Designers (percent frequency) } \\
\hline & & \multirow{2}{*}{$\begin{array}{l}\text { Full sample } \\
(N=489)\end{array}$} & \multicolumn{2}{|c|}{ Brexit sample $(N=143)$} \\
\hline & & & $\begin{array}{l}\text { Affected by Brexit } \\
\qquad(N=88)\end{array}$ & $\begin{array}{l}\text { Not affected by } \\
\text { Brexit }(N=55)\end{array}$ \\
\hline \multirow[t]{2}{*}{ Offshored production } & Yes & 43.35 & 40.91 & 40.00 \\
\hline & No & 56.65 & 59.09 & 60.00 \\
\hline \multirow[t]{10}{*}{ Type of activity offshored* } & Fibers to yarns & 5.65 & - & - \\
\hline & Yarns to fabrics & 8.12 & - & - \\
\hline & Coloring and finishing & 9.88 & - & - \\
\hline & Textile inspection and evaluation & 6.82 & 12.20 & 8.89 \\
\hline & Product design and development & 6.12 & 9.76 & 11.11 \\
\hline & Prototype preparation & 9.76 & 19.51 & 15.56 \\
\hline & Sample development & 14.94 & 25.61 & 22.22 \\
\hline & Garment making & 19.65 & - & - \\
\hline & Pressing/finishing/packaging & 12.12 & 20.73 & 22.22 \\
\hline & Product delivery & 6.12 & 12.20 & 20.00 \\
\hline \multirow[t]{4}{*}{ Production model* } & Cut, Make and Trim & 33.96 & 38.89 & 31.82 \\
\hline & Original Equipment Manufacturing & 38.21 & 27.78 & 36.36 \\
\hline & Original Design Manufacturing & 13.68 & 8.33 & 9.09 \\
\hline & Original Brand Manufacturing & 10.38 & 16.67 & 22.73 \\
\hline \multirow[t]{4}{*}{ Service delivery model* } & Captive (fully owned subsidiary) & 23.05 & - & - \\
\hline & Third-party provider offshore & 50.01 & 86.21 & 75.00 \\
\hline & Partnering & 10.16 & - & - \\
\hline & Intermediaries & 13.28 & 13.79 & 25.00 \\
\hline \multirow[t]{4}{*}{ Host geographical region } & Eastern Europe & 13.40 & 14.00 & 14.29 \\
\hline & Western Europe & 21.18 & 22.00 & 25.71 \\
\hline & China & 24.30 & 24.00 & 17.14 \\
\hline & Other extra-EU countries & 41.12 & 40.00 & 42.86 \\
\hline \multirow{8}{*}{ Offshoring motivations* } & Access to skills and knowledge offshore & 27.05 & 34.21 & 39.53 \\
\hline & Labor cost savings & 25.52 & 31.58 & 27.91 \\
\hline & Trade facilitations & 6.67 & 5.26 & 4.65 \\
\hline & Country-specific conditions & 5.33 & - & - \\
\hline & Access to new markets & 2.67 & 2.63 & 2.33 \\
\hline & Access to raw materials & 14.67 & 17.11 & 13.95 \\
\hline & Access to advanced machinery & 10.29 & 9.21 & 11.63 \\
\hline & Risk diversification & 1.90 & - & - \\
\hline \multirow[t]{3}{*}{ Reshoring } & Implemented & 13.81 & 11.11 & 18.18 \\
\hline & Planned & 9.05 & - & - \\
\hline & Not planned & 77.14 & 88.89 & 81.82 \\
\hline
\end{tabular}

Source: Authors' own elaboration

*The variable included the option "other"

relocated production offshore, $14 \%$ of firms already implemented a reshoring strategy, whereas 9\% have only planned to move manufacturing phases back to the UK. This can add further evidence to the early signs of a domestic revival of the sector.

As mentioned earlier, we collected Brexit-related responses for a random sub-sample of 143 retailers/ designers. Amongst these, $62 \%$ declared to have already been affected by Brexit. Compared to those that had not faced consequences, the affected firms are older and established before the economic and financial crisis (58 vs $40 \%$ ), have a higher share of businesses with 10-49 employees (15 vs $4 \%$ ), and are more represented by retailers (38 vs $27 \%$ ), which work more in the mass- and middle-market segment (49 vs 38\%). Brexit-affected firms have a slightly higher share of businesses targeting the domestic market (46 vs 39\%). Moreover, they tend to offshore somewhat more the phases of prototype preparation and sample development (45 vs 38\%), through third-party provider offshore (86 vs $75 \%$ ) and drawing upon CMT production model (39 vs 


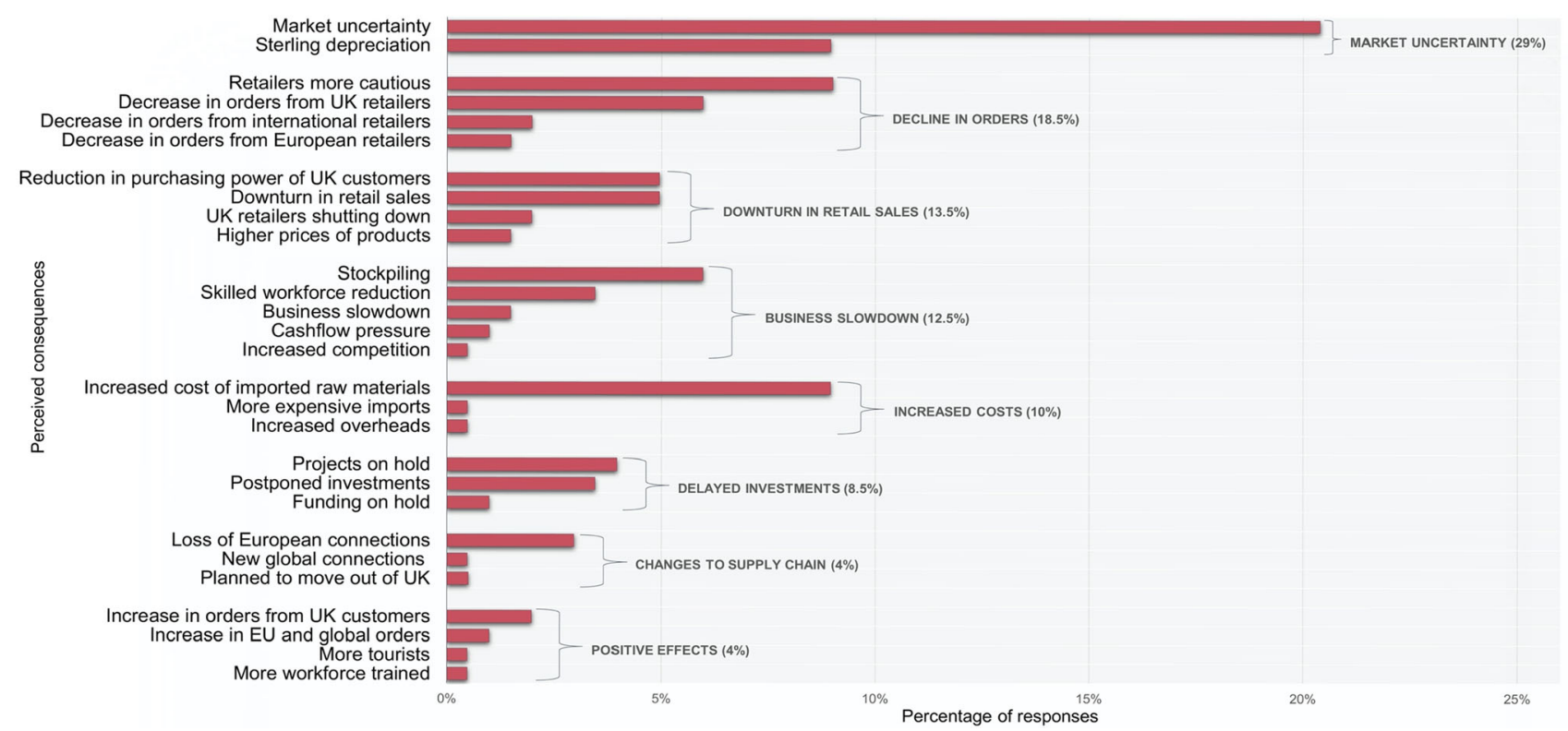

Figure 1 The consequences of Brexit uncertainty for manufacturing firms by theme and relative weight. Source: Authors' own elaboration.

$32 \%)$. While affected and non-affected firms seem to have a similar level of integration along the GVC in terms of offshored activities, those firms that have perceived the consequences of Brexit uncertainty have implemented less reshoring strategies (11 vs 18\%). Moreover, the fact that Brexit-affected firms are older can be interpreted as potentially more established relationships with offshore suppliers. They also offshored more sampling and prototyping activities, which are more difficult to efficiently source domestically. Uncertainty seems to have influenced more retailers than designers and firms targeting the domestic market, which can be perhaps explained by the downturn in the UK retail sales.

\section{Firms' Perceptions: The Consequences of Brexit Uncertainty}

In this section, we present findings from the content analysis of Brexit-related textual data originating from retailers/designers' and manufacturing firms' replies to the following two questions: (a) Has Brexit uncertainty already affected your firm? and (b) If yes, please explain in a few words in which way. We first identified patterns of themes in all answers and coded each response to explore the most frequent topics for both manufacturing firms and retailers/designers. The consistency of firms' perceptions with respect to the Brexit shock was remarkable, and findings are in line with the negative scenario shown by previous research. Figure 1 shows the main consequences of Brexit uncertainty as perceived by manufacturing firms.

Among the firms declaring to have already been affected by Brexit, 29\% indicated market uncertainty, associated with sterling's depreciation and a fluctuating exchange rate, as a major factor with a variety of consequences. According to $18.5 \%$ of respondents, domestic retailers have become extremely cautious and have started relying on less expensive and lower-quality products. Thus, manufacturing firms have experienced a significant decrease in the number of orders from the UK and, to a lesser extent, international and European retailers, particularly because of continuous rising costs as well as of unpredictable future tariffs and delivery times. Other firms (13.5\%) pointed out a downturn in retail sales, following a substantial reduction in the purchasing power of UK costumers and an increase in the price of products, with several brands and high-street shops shutting down (The Guardian, 2019b). For example, some of the replies were: "We are receiving fewer orders as retailers are being extremely cautious", "The whole uncertainty has caused a ripple of resistance from our European markets", and "Brands are liquidating or ordering less due to rising costs".

Others (12.5\%) expressed their difficulties in keeping the business going on, stocking up on raw materials, and experiencing cash flow pressure 


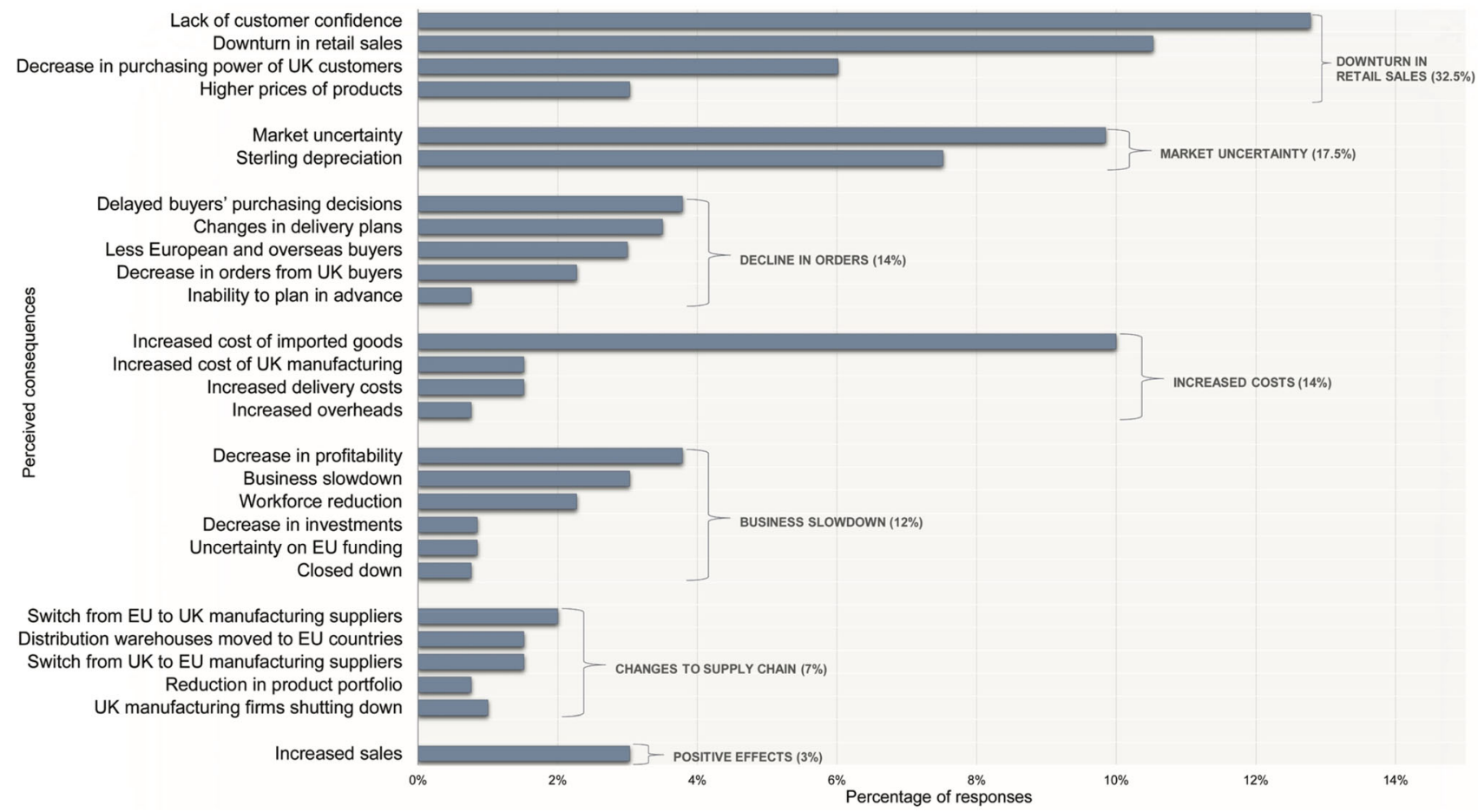

Figure 2 The consequences of Brexit uncertainty for retailers/designers by theme and relative weight. Source: Authors' own elaboration.

and increased foreign competition. They have also witnessed a decrease in the labor force, confirming the trend of some skilled workers going back to their home countries and the reduced inflow of foreign experienced workers (BOP Consulting, 2017; UKFT, 2018b). Some responses were: "Workers have started moving back, labor force is depleting, and skilled labor is going", and "We are now experiencing extreme difficulties in keeping the company going. We have had to lay people off and make redundancies". Other firms (10\%) complained about increased costs, particularly of imported raw materials (e.g., leather, yarns, threads, zip), which have resulted in higher prices and lower demand for products sold in the UK market. A few firms $(8.5 \%)$ declared to have postponed investment plans and delayed projects such as expansion and innovation-related expenditures, also because of uncertainty linked to access to EU funding.

Several manufacturing firms (4\%) indicated to have already lost old connections or established (or planned to establish) new ones along their supply networks, for example by losing larger retailers that have moved production offshore, switching from the UK to other European or international suppliers or moving plants and warehouses to an EU country. Some of their comments were: "We manufacture in UK and also Eastern Europe, however we pulled out of Europe into Far East, holding more stocks of finished goods", and "We have a UK warehouse for distribution in Europe. This is now in doubt and we are planning to move it to Italy".

Only $4 \%$ of manufacturers have witnessed a positive effect, experiencing for example an increase in turnover due to additional orders from UK retailers who sought to source more products in the UK to avoid potential difficulties with foreign suppliers. Moreover, these firms claimed to have observed an increase in the UK workforce trained domestically to develop manufacturing skills, as well as more overseas visitors due to the weaker value of the sterling. Similarly to non-affected firms, these positively affected firms are weakly embedded into the GVC, never implemented an offshoring strategy, and exclusively employ a UKnative skilled workforce.

As reported in Figure 2, a large number of Brexitaffected retailers and designers (32.5\%) witnessed a lack of costumers' confidence due to the extended period of uncertainty, which resulted in a significant reduction of their spending and decline in 
sales since the 2016 referendum. Market uncertainty, the weak value of the sterling, and a fluctuating exchange rate (mentioned by 17.5\%) have resulted in higher costs of domestic production and reduced profitability of products. This effect, in addition to an increase in delivery costs and overhead, was reported by $14 \%$ of this group. The same percentage mentioned a decrease in orders from UK buyers, changes to delivery plans, delayed purchasing decisions and reduced ability to plan in advance and deal with new potential European and overseas customers. Some firms (12\%) claimed to have experienced a slowdown of their businesses, with a reduction in profitability, investments, and workforce (with several foreign employees returning to their home countries, as noted also by manufacturers), with one firm amongst the respondents closing down the activity right after the survey. Firms wrote: "Uncertainty around the new trade agreement has added complexity and reduced our ability to sell within Europe", "We are a small business that has goods manufactured in Europe and the decline in the pound from the referendum onwards has had a marked effect on the profitability of the goods we import", and "I have had no applications from European workers which I have had over the last 20 years in business".

Approximately $7 \%$ of firms claimed to have already applied (or planned to apply) changes to their supply and distribution networks. For example, some of the replies were: "We moved all production to the UK in light of Brexit to make us a 100\% British brand", "To keep my own prices down for the customer, I have undertaken a dynamic pricing strategy and I will be moving future manufacture to Portugal or Italy rather than remaining within the UK", and "We used to have a small production in the UK. Brexit sealed the end of this collaboration". Only $3 \%$ of firms stated to have been positively affected by Brexit with an increase in sales particularly to the EU and US over the last 3 years.

Overall, retail and fashion design firms appeared to be seriously concerned about the possibility of jeopardizing their trading relationships with European and international partners along the GVC. Concerns are reinforced by a negative perception of domestic manufacturing, which most retailers and designers define as expensive and characterized by a lack of firms endowed with adequate technical skills, specialist expertise, machineries, and capable of producing in small batches. Especially micro-sized retailers expressed fears about their future inability, due to lack of adequate financial resources, to trade with the EU without being part of the customs union and single market. Examples of responses were: "I am worried about losing the ease of trading which exists at the moment", "We have had to reduce our product offering to items that can be UK sourced because we are a too small a company to cope with the red tape of importing", and "Those who cannot source the materials that we need for our garments from the UK are stuffed".

\section{DISCUSSION AND CONCLUSION}

There is a large body of theoretical and empirical work studying the effects of trade policy uncertainty on macroeconomic and firm-level performance. Trade policy uncertainty not only reflects in financial market volatility, but it immediately affects firm choices. Previous studies have shown that threats to raise tariffs and non-tariff barriers are a dangerous deterrent to international trade flows, particularly when production takes place in global supply chains (Crowley et al. 2018; Harrigan \& Venables; 2006; Osnago et al., 2018). A less-certain trade environment induces firms to reduce or postpone investments (domestic and FDI), and consumers to save precautionarily, which is reflected in lower imports. It may also affect GVC participation by dampening domestic firms' incentives to build and consolidate relationships with international input suppliers, eventually leading to source less inputs from abroad, and also reducing the incentives for foreign firms to invest in the domestic market (Bank of England, 2019; Constantinescu et al., 2019).

In line with this literature, we show that Brexit uncertainty over future trade agreements and policies - started in the wake of the referendum in June 2016 - has affected a significant number of firms operating upstream and downstream of the UK T\&A value chain, which shows clear signs of disruption and ongoing restructuring. The weak value of the sterling and a fluctuating exchange rate have been major factors in firms' perception of Brexit uncertainty. These have increased the cost of imported raw materials, which has in turn resulted in higher prices and lower demand for domestic production. Manufactures have experienced a reduction in orders from more cautious UK, European, and international retailers, stocked up on raw materials - a rather unsustainable precaution to counterbalance the impact of the shock - and seen investment plans delayed or held back. Firms 
operating downstream in the value chain have witnessed a decline in orders from European, international, and UK buyers and a significant drop in sales due to a reduction in the purchasing power of domestic consumers and an increase in the price of products. Overall, it has been more difficult for many firms to keep the business going, with some of them experiencing cash flow pressure and a first decline in the workforce. Some companies have started changing their supply chain by switching from EU to UK suppliers (and vice versa) or moving plants and warehouses to other countries. Retailers and designers appear the most worried about the threats to their trading relationships within Europe and internationally, because of the difficulties in sourcing from UK suppliers.

Our findings also provide some preliminary evidence of the way the (perceived) effects of trade policy uncertainty may vary depending on the position, production phase, and degree of integration in the GVC. First, the small share of suppliers claiming to have been positively affected or nonaffected by Brexit are weakly integrated into the GVC. In particular, manufacturers involved in backward linkages with extra-EU suppliers and supplying more international buyers seem to be more exposed to Brexit uncertainty, due to the increased cost of imported inputs and a more expensive and less competitive domestic manufacturing. The level of integration in GVCs seems to be less significant for lead firms in terms of Brexit awareness, although firms that have recently implemented reshoring strategies have been less affected by uncertainty. Second, the type of production phases offshored seems to be associated with a different perception of uncertainty, as manufacturing firms with offshore production that involve inputs and components appear more sensitive to it. Ambiguity in future trade relations has a stronger negative effect on intermediate inputs that go into further processing, due to enhanced perceptions of shocks associated with a potential disruption of the entire production process in case of late/failed arrival of components (Harrigan \& Venables, 2006), which could only temporarily be offset by stockpiling on raw materials and other components. Uncertainty seems to have also influenced lead firms offshoring more sampling and prototyping activities, which are more difficult to efficiently source domestically.

Ongoing research aims at exploring in depth the internationalization strategies of firms in the UK T\&A value chain, in order to grasp possible trends and implications in terms of reshoring stages of production. The analysis of the industry inward and outward FDI would also add vital information to the GVC sensitivity to the Brexit (and other) trade shocks.

In a longer-term perspective, irrespective of the form of the future economic and political relationships between the EU and the UK, which at the time of writing are still under negotiation, firms operating upstream and downstream of the T\&A value chain will have to deal with changes to their trade exchanges and production networks (UKFT, 2019). While it is obviously recommendable that the UK government does everything possible to conclude a favorable deal with the EU and other countries, policy support will be crucial to help the sector, which in the long term might face both an increase in domestic demand and a drastic reduction in linkages with international lead firms. In this regard, a recent research stream has emphasized the role of the state as a "facilitator" in the integration and upgrading of firms within GVCs, for example by promoting tax incentives, R\&D subsidies, skill formation and training programs, and investment support (Horner, 2017). It has also been argued that national industrial policies should be revisited in the context of GVCs (Gereffi \& Sturgeon, 2013).

To date - as shown also by our findings - there is a general perception of a lack of concrete action by the government to support the viability of the UK T\&A industry. The need for initiatives oriented towards the restructuring of this sector and, crucially, its prompt inclusion in the UK Industrial Strategy, is made more compelling by the withdrawal of the UK from the EU. Interventions are particularly needed to help the industry undertake a process of functional, product, and process upgrading (Fernandez-Stark et al., 2011; Pietrobelli \& Staritz, 2018). The development of new skills and capabilities, the adoption of more innovative machineries and equipment, the upgrading of product quality and standards, and a deeper integration in some production phases of the value chain - such as sampling and prototyping - would help the sector to face the big challenges ahead in European and global markets, and to boost the confidence of domestic retailers and designers.

Firm-level views on changes in the broader economic landscape (e.g., new policies) and the implications for the behavior, structures, and strategies of different types of firms has been recently deemed a key contribution for the "policy turn" of IB research. Indeed, these "private" perspectives can support international economics, 
traditionally more prominent in policy circles, in developing a more "public" or "societal" viewpoint on international trade, which is needed to influence policy discussion (Van Assche, 2018). Survey research can be regarded as a particularly useful tool for grasping these firm-level views. In this paper, we drew upon data from an original survey to explore different firms' perceptions of the consequences of Brexit-related policy uncertainty. Future IB research could rely upon new originally designed surveys as a method for investigating firm perspectives on other policy-related events and the way these perspectives may vary across different types of firms.

\section{ACKNOWLEDGEMENTS}

The authors would like to thank first and above all Mr. Adam Mansell, CEO of the UK Fashion and Textile Association (UKFT) for his invaluable help and encouraging support to the methodology and data collection. We would also like to thank for their helpful comments and suggestions the participants of the JIBP Paper Development Workshop of the 45th European International Business Academy (EIBA) Annual Conference, 2019, University of Leeds. The authors are also extremely grateful to the editor and three anonymous reviewers for their constructive and useful comments. The authors are solely responsible for any errors contained in the paper.

\section{NOTES}

${ }^{1}$ On June 23, 2016, the UK people voted to leave the European Union. The UK formally left the EU on January 31, 2020, and the government is currently negotiating a new trade deal with the EU and third countries. The implementation period will last until December 31, 2020, when the UK will leave the EU single market and CU. At the time of writing, there is still uncertainty over the future form of Brexit (i.e., deal or no-deal).

${ }^{2}$ Conceptual perspectives on GVCs slightly differ in the literature on the spread of value-added creation and distribution across firm boundaries and geographical borders (e.g., global production networks, global commodity chains). For differences in these conceptualizations, see, e.g., Coe, Dicken and Hess (2008). The GVC focus on the specific industry and on the governance of inter- firm transactions makes it the most suitable approach for the study here presented.

${ }^{3}$ Non-tariff barriers restrict imports or exports of goods or services through mechanisms other than the imposition of tariffs. These include for example import quotas, subsidies, customs delays, technical barriers, and other systems preventing or impeding trade (UKFT, 2018a).

${ }^{4}$ The NAFTA is a deal amongst the United States, Canada and Mexico entered into force in January 1994 and designed to remove tariff barriers and other obstacles to closer integration of the three countries. Under the leadership of President Donald J. Trump, NAFTA was recently renegotiated with the United States-Mexico-Canada Agreement (USMCA) (WTO, 2019).

${ }^{5}$ The AFTA is a trade agreement signed in 1992 to support local trade and manufacturing in all ASEAN countries (i.e., Brunei, Cambodia, Indonesia, Laos, Malaysia, Myanmar, the Philippines, Singapore, Thailand and Vietnam) and facilitate economic integration regionally and globally (Association of Southeast Asian Nations, 2019).

${ }^{6}$ The VUCA acronym, first introduced in 1987 and used by the US Army War College, has been increasingly adopted to describe the volatility, uncertainty, complexity, and ambiguity associated with new trends (Van Tulder et al., 2020).

${ }^{7}$ Firms supplying more standardized inputs could more easily offer their products to other markets once a trade policy reversal takes place in a certain country (Osnago et al., 2018).

${ }^{8}$ As an EU member, the UK currently participates in around 40 free trade agreements with over 70 countries. At the moment of writing, 28 trade deals have been signed, whereas the rest are still under discussion (UK Government, 2020).

${ }^{9}$ The common external trade policy eliminates the need for rules of origin checks at intra-EU borders since the regime for imports from outside the $\mathrm{CU}$ is the same at all points of entry (Gasiorek et al., 2018).

${ }^{10}$ The EEA was established in 1994 to give European countries that are not part of the EU a way to become members of the Single Market. The EEA comprises all EU members and three non-EU countries: Iceland, Liechtenstein and Norway.

${ }^{11}$ According to WTO rules, all countries have to be treated equally through the application of the "Most Favored Nation" (MFN) principle, stating that all countries, in the absence of a specific trade agreement or customs union, are subject to the 
same tariffs, customs checks, and barriers to trade (Keane, 2018).

${ }^{12}$ According to Boris Johnson's conservative party, which won majority in the last UK general elections in December 2019, future trade relations with the EU should be based on a free trade agreement similar to the EU-Canada deal, which would entail the UK leaving both single market and customs union, while maintaining tariff-free and quota-free trade with the EU for all (or almost) products.

${ }^{13}$ The Brexit implications extend far beyond trade agreements, as the complex issue of Northern Ireland (to mention just one) has shown. For the sake of consistency and brevity, we do not cover here other dimensions of the debate.

${ }^{14}$ The wholesale sector accounted for 43,000 people, while 276,000 people were reported to be employed within retail of clothing in specialist stores in 2017.

${ }^{15}$ To date, there are no specific SIC codes associated with fashion design activities, which are included amongst the SIC 2007 categories dedicated to textile and apparel manufacturing $(13,14$, and 15) (DCMS, 2016).

${ }^{16}$ Manufacturing firms were identified according to the three-digit codes: 13.1 Preparation and spinning of textile fibers, 13.2 Weaving of textiles, 13.3. Finishing of textiles, 14.1 Manufacture of wearing apparel, except fur apparel, 14.2 Manufacture of articles of fur, 14.3 Manufacture of knitted and crocheted apparel, 15.1 Tanning and dressing of leather; manufacture of luggage, handbags, saddlery and harness; dressing and dyeing of fur, 15.2 Manufacture of footwear. The category 13.9 Manufacture of other textiles was excluded to focus the analysis on the fashion-related industry. Retailers were identified according to the four-digit codes 47.71 Retail sale of clothing in specialized stores, 47.72 Retail sale of footwear and leather goods in specialized stores and 47.82 Retail sale via stalls and markets of textiles, clothing and footwear (SIC 2007).

\section{REFERENCES}

Armstrong, J.S., \& Overton, T.S. 1977. Estimating nonresponse bias in mail surveys. Journal of Marketing Research, 14(3), 396402.

Bailey, D., \& Budd, L. 2017. The political economy of Brexit. Newcastle Upon Tyne: Agenda Publishing Limited.

Baker, S. R., Bloom, N., \& Davis, S. J. 2016. Measuring Economic Policy Uncertainty. Quarterly Journal of Economics, 131(4), 1593-1636.
${ }^{17}$ According to official statistics from the InterDepartmental Business Register (IDBR - Office for National Statistics, 2019), manufacturing firms under the same SIC 2007 codes account for 5825 whereas retailers for 14,415 firms (see Appendix).

${ }^{18}$ We relied upon the software Qualtrics to create and distribute the survey (https://www.qualtrics. com).

${ }^{19}$ The first question of the survey directs respondents to different sets of questions according to the typology of firm (i.e., manufacturer or retailer/ designer).

${ }^{20}$ The survey was originally designed to explore offshoring and reshoring in the industry. Due to the complexity of this topic for firms operating downstream in the value chain, the section of the survey tailored to retailers and designers was deemed too long to also cover Brexit. Therefore, the specific section focused on Brexit was sent later to a random sub-sample of retail and design firms. While we collected Brexit-related data for a limited number of firms, this choice allowed us to gather more accurate responses from retailers and designers.

${ }^{21}$ The distribution of manufacturing firms (and of retailers/designers) in the sample is skewed towards micro firms, in line with the figures of the InterDepartmental Business Register (IDBR - ONS, 2019) showing that $82 \%$ of manufacturers and $90 \%$ of retailers under the same SIC 2007 codes are micro firms (see Appendix). The higher percentage of micro manufacturing firms in the total population compared to our sample can be the result of the inclusion in IDBR data of fashion design businesses amongst manufacturers, which prevents data from being strictly comparable.

${ }^{22}$ In the survey, we define "offshoring" as the relocation of the entire or part of production abroad, and "reshoring" as the relocation of the entire or part of production (previously offshored) back to the UK.

Baker, S. R., Bloom, N., \& Davis, S. J. 2019. The Extraordinary Rise in Trade Policy Uncertainty. VOX CEPR Policy Portal.

Balassa, B. 1961. The theory of economic integration. Homewood: R.D. Irwin.

Baldwin, R. 2016. The great convergence: Information technology and the new globalization. Cambridge: Harvard University Press. 
Baldwin, R., \& Lopez-Gonzalez, J. 2015. Supply chain trade: A portrait of global patterns and several testable hypotheses. The world economy, 38(11), 1682-1721.

Bank of England. 2019. Uncertainty and Brexit. Section 4 of the Monetary Policy Report, November 2019. https://www. bankofengland.co.uk/monetary-policy-report/2019/ november-2019/in-focus-unce-rtainty-and-brexit. Accessed 5 January 2020.

Baruch, Y., \& Holtom, B.C. 2008. Survey response rate levels and trends in organizational research. Human Relations, 61(8), 1139-1160.

Bernanke, B.S. 1983. Irreversibility, uncertainty, and cyclical investment. The Quarterly Journal of Economics, 98(1), 85-106.

Bloom, N. 2009. The impact of uncertainty shocks. Econometrica, 77(3), 623-685.

Bloom, N., Bond, S., \& Reenen, J.V. 2007. Uncertainty and investment dynamics. Review of Economic Studies, 74(2), 391415.

Bloom, N., Bunn, P., Chen, S., Mizen, P., Smietanka, P., \& Thwaites, G. 2019b. The impact of Brexit on UK firms. NBER Working Paper No. 26218.

Bloom, N., Bunn, P., Chen, S., Mizen, P., Smietanka, P., Thwaites, G., \& Young, G. 2019a. Brexit and uncertainty: Insights from the Decision Maker Panel. Bank of England Working Paper No. 780.

BOP Consulting. 2017. The East London Fashion Cluster. Draft strategy and action plan. https://www.fashion-district.co.uk/ wp-content/uploads/2018/09/East-London-Fashion-ClusterDraft-and-Strategy-Plan.pdf. Accessed 11 August 2020.

Brakman, S., Garretsen, H., \& Kohl, T. 2017. Consequence of Brexit and options for a "Global Britain". Papers in Regional Science, 97(1), 55-72.

British Fashion Council (BFC). 2015. High-end designer manufacturing report. London: British Fashion Council. http:// www.britishfashioncouncil.com/. Accessed 17 February 2020.

British Fashion Council (BFC). 2019. The impact of a no deal Brexit for British fashion industry. https://www. britishfashioncouncil.co.uk/pressreleases/The-Impact-of-NoDeal-Brexit-for-British-Fashion-Industry. Accessed 6 April 2020.

Buckley, P.J., Doh, J.P., \& Benischke, M.H. 2017. Towards a renaissance in international business research? Big questions, grand challenges, and the future of IB scholarship. Journal of International Business Studies, 48(9), 1045-1064.

Cappariello, R., Damjanovic, M., Mancini, M., \& Caffarelli, F.V. 2018. EU-UK Global Value Chain trade and the indirect costs of Brexit. Questioni di Economia e Finanza (Occasional Papers) 468, Bank of Italy, Economic Research and International Relations Area.

Cappariello, R., Franco-Bedoya, S., Gunnella, V., \& Ottaviano, G. 2020. Rising protectionism and global value chains: Quantifying the general equilibrium effects. CEO Discussion Paper No 1682.

Casadei, P., \& lammarino, S. 2020. The dynamics of global value chains: Offshoring and reshoring in the UK textile and apparel industry. LSE, mimeo.

Celly, K.S., Spekman, R.E., \& Kamauff, J.W. 1999. Technological uncertainty, buyer preferences and supplier assurances: An examination of pacific rim purchasing arrangements. Journal of International Business Studies, 30(2), 297-316.

Comotti, S., Crescenzi, R. \& lammarino, S. 2020. Foreign direct investment, global value chains and regional economic development. European Commission Directorate-General for Regional and Urban Policy. http://bit.ly/2EBX4Yy. Accessed 22 November 2019.

Constantinescu, C., Mattoo, A., \& Ruta, M. 2019. Policy uncertainty, trade and global value chains. Some facts, many questions. Policy research working paper. World Bank Group.

Cook, C., Heath, F., \& Thompson, R. L. 2000. A meta-analysis of response rates in web- or internet-based surveys. Educational and Psychological Measurement, 60(6), 821-836.
Crowley, M.A., Exton, O., \& Han, L. 2018. Renegotiation of trade agreements and firm exporting decisions: Evidence from the impact of Brexit on UK exports. CEPR Discussion Paper No. DP13446.

Curran, L. 2018. The impact of Brexit on global value chains and governance. In B. Vickers \& S. Khorana (Eds.), Navigating uncertainty: Towards a post-Brexit trade and development agenda: 31-39. London: Commonwealth Secretariat 2018.

Davis, S. J. 2019. Rising Policy uncertainty. NBER Working Paper No. 26243.

De Backer, K., \& Flaig, D. 2017. The future of global value chains: Business as usual or "a new normal"? OECD Science, Technology and Industry Policy Papers, No. 41, OECD Publishing, Paris. https://doi.org/10.1787/d8da8760-en. Accessed 22 August 2019.

De Lyon, J., \& Dhingra, S. 2019. Economic performance since the EU referendum. London School of Economics and Political Science: Centre for Economic Performance.

Delios, A., \& Henisz, W.J. 2003. Policy uncertainty and the sequence of entry by lapanese firms, 1980-1998. Journal of International Business Studies, 34(3), 227-241.

Department of trade and industry (DTI). 2000. A National Strategy for the UK Textile and Clothing Industry. Textiles and Clothing Strategy Group. London: Department of Trade and Industry.

Dhingra, S. 2019. Brexit and the Future of Trade. In G. Kelly, \& N. Pearce (Eds.) Britain Beyond Brexit. The Political Quarterly, 90(2): 21-31.

Dhingra, S., Ottaviano, G.I.P., Sampson, T. \& Van Reenen, I. 2016. The consequences of Brexit for UK trade and living standards. CEP BREXIT Analysis No.2 (CEPBREXIT02. London School of Economics and Political Science, CEP, London, UK.

Dhingra, S. \& Sampson, T. 2019. Brexit Economics. Centre for Economic Performance, Paper EA048, November.

Dixit, A. K. 1989. Entry and exit decisions under uncertainty. Journal of Political Economy, 97(3), 620-638.

Douch, M. M., Du, J., \& Vanino, E. 2019. Defying gravity? Policy uncertainty and trade diversion. LBGCBP Research Paper No. 3, Aston Business School.

Escaith, H. 2018. Mapping the UK Domestic and Global Value Chains from a Brexit Perspective. https://papers.ssrn.com/ sol3/papers.cfm?abstract_id=3212163. Accessed 4 July 2019.

Evenett, S. I. 2019. Protectionism, state discrimination, and international business since the onset of the Global Financial Crisis. Journal of International Business Policy, 2(1), 9-36.

Evenett, S.J., \& Fritz, J. 2019. Going it alone? Trade policy after three years of populism. The 25th Global Trade Alert Report. CEPR Press.

Fernandez-Stark, K., Frederick, S., \& Gereffi, G. 2011. The apparel global value chain. Economic upgrading and workforce development: Duke University Centre on Globalization, Governance and Competitiveness.

Financial Times. 2014. Made in Britain: Fashion retailers return to UK manufacturing. https://www.ft.com/content/8c37ac3a2946-11e4-8b81-00144feabdc0. Accessed 14 July 2020.

Financial Times. 2016. Will UK fashion survive Brexit? https:// www.ft.com/content/b163a94c-9f77-11e6-891eabe238dee8e2. Accessed 14 April 2020.

Financial Times. 2020. Covid and Brexit could see UK manufacturers bringing it all back home. https://www.theguardian. com/business/2020/nov/23/covid-and-brexit-could-see-ukmanufacturers-bringing-it-all-back-home. Accessed 24 November 2020.

Forza, C. 2002. Survey research in operations management: A process-based perspective. International Journal of Operations \& Production Management, 22(2), 152-194.

Fratocchi, L., \& Di Stefano, C. 2019. Manufacturing reshoring in the fashion industry: A literature review. World Review of Intermodal Transportation Research, 8(4), 338-365.

Froud, J., Haves, S., Wei, H., \& Williams, K. 2017. Coming back? Capability and precarity in the UK textiles and apparel. https:// 
foundationaleconomycom.files.wordpress.com/2017/02/. Accessed 4 July 2019.

Fusacchia, I., Salvatici, L., \& Winters, A. 2019. Brexit and Global Value Chains: No deal is still costly. UK Trade Policy Observatory. https://blogs.sussex.ac.uk/uktpo/publications/brexitand-global-value-chains-no-deal-is-still-costly/. Accessed 17 August 2019.

Gasiorek, M., Serwicka, I., \& Smith, A. 2018. Which manufacturing industries and sectors are most vulnerable to Brexit? The World Economy, 42(1), 21-56.

Gereffi, G. 1999. International trade and industrial upgrading in the apparel commodity chain. Journal of International Economics, 48(1), 37-70.

Gereffi, G. 2019. Global value chains and international development policy: Bringing firms, networks, and policy-engaged scholarship back in. Journal of International Business Policy, 2(3), 195-210.

Gereffi, G., \& Frederick, S. 2010. The global apparel value chain, trade, and the crisis: Challenges and opportunities for developing countries. Policy Research Working Paper No. 5281, World Bank.

Gereffi, G., \& Sturgeon, T. 2013. Global value chain-oriented industrial policy: The role of emerging economies. In D. Elms \& P. Low (Eds.), Global value chains in a changing world (pp. 329-360. Geneva: WTO Publications.

Gilchrist, S., J., Sim, W., \& Zakrajšek, E. 2014. Uncertainty, Financial Frictions, and Investment Dynamics. NBER Working Paper No. 20038.

Graziano, A., Handley, K., \& Limão, N. 2018. Brexit uncertainty and trade disintegration. NBER Working paper No. 25334.

Graziano, A., Handley, K., \& Limão, N. 2020. Brexit uncertainty: Trade externalities beyond Europe. AEA Papers and Proceedings, 110, 552-556.

Greater London Council (GLC). 1985. The London industrial strategy. Greater London Council (GLC).

Hammer, N., \& Plugor, R. 2016. Near-sourcing UK apparel: Value chain restructuring, productivity and the informal economy. Industrial Relations Journal, 47(5), 402-416.

Handley, K. 2014. Exporting under trade policy uncertainty: Theory and evidence. Journal of International Economics, 94(1), 50-66.

Handley, K., \& Limão, N. 2015. Trade and investment under policy uncertainty: Theory and firm evidence. American Economic Journal: Economic Policy, 7(4), 189-222.

Handley, K., \& Limão, N. 2017. Policy uncertainty, trade, and welfare: Theory and evidence for China and the United States. American Economic Review, 107(9), 2731-2783.

Harrigan, J., \& Venables, A.J. 2006. Timeliness and agglomeration. Journal of Urban Economics, 59(2), 300-316.

Harzing, A.W., Reiche, S., \& Pudelko, M. 2012. Challenges in international survey research: A review with illustrations and suggested solutions for best practice. European Journal of International Management, 7(1), 112-134.

Hassan, T.A., Hollander, S., Van Lent, L., \& Tahoun, A. 2020. The global impact of Brexit uncertainty. NBER Working Paper No. 26609.

Horner, R. 2017. Beyond facilitator? State roles in global value chains and global production networks. Geography Compass, 11(2), e12307.

ljtsma, P., Levell, P., Los, B., \& Timmer, M.P. 2018. The UK's participation in global value chains and its implications for Post-Brexit trade policy. Fiscal Studies, 39(4), 651-683.

Keane, J. 2018. Brexit and global value chains: The costs of transition to new trade governance structures. In B. Vickers \& S. Khorana (Eds.), Navigating uncertainty: Towards a post-Brexit trade and development agenda: 25-30. London: Commonwealth Secretariat 2018.

Macchion, L., Moretto, A., Caniato, F., Caridi, M., Danese, P., \& Vinelli, A. 2015. Production and supply network strategies within the fashion industry. International Journal of Production Economics, 163(1), 173-188.
Matanda, M.J., \& Freeman, S. 2009. Effect of perceived environmental uncertainty on exporter-importer inter-organisational relationships and export performance improvement. International Business Review, 18(1), 89-107.

McKinsey \& Company. 2019a. Is apparel manufacturing coming home? Nearshoring, automation, and sustainability-establishing a demand-focused apparel value chain. https://www. mckinsey.com/industries/retail/our-insights/is-apparelmanufacturing-coming-home. Accessed 28 July 2020.

McKinsey \& Company. 2019b. The State of Fashion 2019. https://www.mckinsey.com//media/McKinsey/Industries/ Retail/Our\%20Insights/The\%20State\%20of\%20Fashion\% 202019\%20A\%20year\%20of\%20awakening/The-State-ofFashion-2019-final.ashx. Accessed 19 July 2019.

McKinsey Global Institute. 2019. Globalization in transition: the future of trade and value chains. https://www.mckinsey.com/ $\sim /$ media/mckinsey/featured\%20insights/innovation/ globalization\%20in\%20transition\%20the\%20future\%20of\% 20trade\%20and\%20value\%20chains/mgi-globalization\% 20 in\%2transition-the-future-of-trade-and-value-chains-fullreport.ashx. Accessed 8 July 2019.

Miroudot, S., Rouzet, D., \& Spinelli, F. 2013. Trade Policy Implications of Global Value Chains: Case Studies. OECD Trade Policy Papers, No. 161, OECD Publishing. https://www. oecdilibrary.org/trade/trade-policy-implications-of-globalvalue-chains_5k3tpt2t0zs1-en. Accessed 13 August 2019.

Mulabdic, A., Osnago, A., \& Ruta, M. 2017. Deep integration and UK-EU trade relations. World Bank Group. Policy Research Working Paper 7947.

Nguyen, Q., Kim, T., \& Papanastassiou, M. 2018. Policy uncertainty, derivatives use, and firm-level FDI. Journal of International Business Studies, 49(1), 96-126.

Novy, D., \& Taylor, A. M. 2014. Trade and Uncertainty. Working Paper No. 19941. Cambridge, MA: National Bureau of Economic Research.

Osnago, A., Piermartini, R., \& Rocha, N. 2018. The heterogeneous effects of trade policy uncertainty. How much do trade commitments boost trade? Policy research working paper 8567, World Bank Group.

Pastor, L., \& Veronesi, P. 2013. Uncertainty about government policy and stock prices. Journal of Finance, 67(4), 1219-1264.

Pickles, J., Plank, L., Staritz, C., \& Glasmeier, A. 2015. Trade policy and regionalisms in global clothing production networks. Cambridge Journal of Regions, Economy, and Society, 8(3), 381-402.

Pierce, J.R., \& Schott, P.K. 2016. The surprisingly swift decline of US manufacturing employment. American Economic Review, 106(7), 1632-1662.

Pietrobelli, C., \& Staritz, C. 2018. Upgrading, interactive learning, and innovation systems in value chain interventions. European Journal of Development Research, 30(3), 557-574.

Robinson, P.K., \& Hsieh, L. 2016. Reshoring: A strategic renewal of luxury clothing supply chains. Operations Management Research, 9(89), 89-101.

Salh, S., Nyfoudi, M., \& De Ruyter, A. 2017. Future regulation of the UK workforce. In D. Bailey \& L. Budd (Eds.), The political economy of Brexit. Newcastle Upon Tyne: Agenda Publishing Limited.

Song, S. 2013. FDI structure, investment specificity, and multinationality value under host market uncertainty. Management International Review, 53(6), 795-817.

Sun Tam, P. 2018. Global trade flows and economic policy uncertainty. Applied Economics, 50(34-35), 1-17.

Taglioni, D., \& Zavacka, V. 2012. Innocent Bystanders: How foreign uncertainty shocks harm exporters. World Bank Policy Research Working Paper No. 6226.

The Alliance Project. 2017. Realising the growth potential of UK fashion and textile manufacturing. https://www.ukft.org/ business-advice/industry-reports-and-stats/. Accessed 17 February 2020. 
The European Apparel and Textile Federation (Euratex). 2017. For a smart and smooth Brexit. http://pr.euractiv.com/sites/ default/files/pr/EURATEX_Brexit_Position_paper.pdf. Accessed 11 April 2020.

The Guardian. 2019a. Brexit uncertainty hits UK manufacturing sector. https://www.theguardian.com/business/2019/nov/ 01/brexit-uncertainty-hits-manufacturing-sector. Accessed 4 January 2020.

The Guardian. 2019b. Thousands of UK shops left empty as high street crisis deepens. https://www.theguardian.com/business/ 2019/may/02/thousands-of-uk-shops-left-empty-as-highstreet-crisis-deepens. Accessed 14 May 2020.

UK Fashion \& Textile Association (UKFT). 2018a. Fashion \& textiles post Brexit. http://textilehouse.co.uk/wp-content/ uploads/UKFT-Brexit-Position-Paper.pdf. Accessed 16 August 2020.

UK Fashion \& Textile Association (UKFT). 2018b. The UK Fashion and Textiles Association compendium of UK textiles and apparel manufacturing data. https://s3-eu-west1.amazonaws. com/ukft/wp-content/uploads/2018/05/15161734/

DOWNLOAD-UKFT-Industry-Statistics-2016-17.pdf. Accessed 14 August 2020.

UK Fashion \& Textile Association (UKFT). 2019. No-deal Brexit would cost UK fashion and textile industry $£ 870 \mathrm{~m}$. https:// www.ukft.org/no-deal-brexit-could-cost-uk-fashion-andtextile-industry-870m. Accessed 24 October 2019.
UK Government. 2019. Global Britain: delivering on our international ambition. https://www.gov.uk/government/ collections/global-britain-delivering-on-our-internationalambition. Accessed 5 April 2020.

UK Government. 2020. Existing UK trade agreements with nonEU countries. https://www.gov.uk/guidance/uk-tradeagreements-with-non-eu-countries. Accessed 12 September 2020.

Van Assche, A. 2018. From the editor: Steering a policy turn in international business-opportunities and challenges. Journal of International Business Policy, 1(6), 117-127.

Van Assche, A., \& Gangnes, (2019. Global value chains and the fragmentation of trade policy coalitions. Transnational Corporations Journal, 26(1), 31-60.

Van Tulder, R., Verbeke, A., \& Jankowska, B. 2020. International business in a VUCA world: The changing role of states and firms. United Kingdom: Emerald Publishing Limited.

Vandenbussche, H., Connell, W., \& Simons, W. 2017. Global value chains, trade shocks, and jobs: an application to Brexit. Ku Leuven, Centre for Economic Studies. Discussion Paper Series DPS17.13.

Worrell, J.H., \& Miller, N.J. 2018. Brexit's potential impact on apparel manufacturing and luxury fashion. Journal of Textile Engineering and Fashion Technology, 4(6), 389-391.

See Table 5.

\section{APPENDIX}

Table 5 Total population of UK T\&A manufacturing firms and retailers.

\begin{tabular}{llcr}
\hline Variable & Category & $\begin{array}{c}\text { Manufacturing firms (5825) } \\
\text { Percent frequency }\end{array}$ & $\begin{array}{r}\text { Retailers (14,415) } \\
\text { Percent frequency }\end{array}$ \\
\hline Number of employees & $0-9$ (micro) & 81.89 & 89.56 \\
& $10-49$ (small) & 14.85 & 8.39 \\
& $50-249$ (medium) & 3.00 & 1.25 \\
& $250+$ (large) & 0.26 & 0.80 \\
\hline
\end{tabular}

Source: Authors' own elaboration

Data were retrieved from the Inter-Departmental Business Register (IDBR) - (Office for National Statistics, 2019). Manufacturers were identified according to the three-digit SIC codes: 13.1 Preparation and spinning of textile fibers, 13.2 Weaving of textiles, 13.3. Finishing of textiles, 14.1 Manufacture of wearing apparel, except fur apparel, 14.2 Manufacture of articles of fur, 14.3 Manufacture of knitted and crocheted apparel, 15.1 Tanning and dressing of leather; manufacture of luggage, handbags, saddlery and harness; dressing and dyeing of fur, 15.2 Manufacture of footwear. Retailers were identified according to the four-digit codes 47.71 Retail sale of clothing in specialized stores, 47.72 Retail sale of footwear and leather goods in specialized stores, and 47.82 Retail sale via stalls and markets of textiles, clothing, and footwear (SIC 2007)

Fellow. Her research interests lie in the areas of international business, development studies, and economic geography.

Patrizia Casadei is Post-doctoral Research Fellow at the Science Policy Research Unit (SPRU), University of Sussex. Prior to joining SPRU, she was Post-doctoral Researcher at the Department of Geography \& Environment of the London School of Economics and Political Science, where she is now Visiting

Simona Iammarino is Professor of Economic Geography in the Department of Geography \& Environment of the London School of Economics and Political Science. She was Head of Department (2014-2017), and member of the LSE Council 
(2016-2020). She is affiliate faculty member at the Gran Sasso Science Institute (Italy), Fellow of the
Academy of Social Sciences, and Fellow of the Regional Studies Association.

Publisher's Note Springer Nature remains neutral with regard to jurisdictional claims in published maps and institutional affiliations.

Accepted by Ari Van Assche, Deputy Editor, 18 December 2020. This article has been with the authors for five revisions. 